\title{
51. ORGANIC GEOCHEMICAL COMPARISON OF CRETACEOUS BLACK SHALES AND ADJACENT STRATA FROM DEEP SEA DRILLING PROJECT SITE 603, OUTER HATTERAS RISE 1
}

\author{
Keith W. Dunham, Philip A. Meyers, and Pamela L. Dunham, The University of Michigan²
}

\begin{abstract}
Organic matter contents of black shales from the Cretaceous Hatteras and Blake-Bahama formations have been compared to those from surrounding organic-poor strata using $\mathrm{C} / \mathrm{N}$ ratios, $\delta^{13} \mathrm{C}$ values, and distributions of extractable and nonsolvent-extractable, long-chain hydrocarbons, acids, and alcohols. The proportion of marine and land-derived organic matter varies considerably among all samples, although terrigenous components generally dominate. Most black shales are hydrocarbon-poor relative to their organic-carbon concentrations. Deposition of the black shales in Hole 603B evidently occurred through turbiditic relocation from shallower landward sites and rapid reburial at this outer continental rise location under generally oxygenated bottom-water conditions.
\end{abstract}

\section{INTRODUCTION}

Occurrences of dark-colored layers of Cretaceous rocks having relatively high concentrations of organic matter have been found in numerous locations studied as part of the Deep Sea Drilling Project (DSDP). The distribution of such occurrences in the North Atlantic Ocean has been discussed by Arthur (1979), Tucholke and Vogt (1979), Thierstein (1979), Graciansky et al. (1981), Weissert (1981), and Waples (1983), among others, with the intent of identifying the paleoceanographic factors involved in the formation of these unusual strata, commonly called "black shales." Improved preservation of organic matter, increased contribution of continental organic matter to oceanic basins, and enhanced production of marine organic matter are some of the factors that have been suggested. Because these three possibilities affect the character of the organic content of black shales, the organic matter in North Atlantic examples has been investigated; these investigations are summarized by Tissot et al. (1980), Summerhayes (1981), Katz and Pheifer (1982), and Graciansky et al. (1982). Varying proportions of marine and terrigenous organic constituents are found in sediments deposited at different times and locations in the Cretaceous Atlantic Ocean. A comparison of the organic matter contained within black shales with that of the adjacent organic-carbon-poor lithologies further contributes to this information. In this chapter, we describe comparisons of analyses done on black shales and closely bedded strata from the Hatteras and Blake-Bahama formations in the western North Atlantic Ocean.

\section{Methods}

Twenty-five Hole 603B samples from different ages in the Cretaceous were selected on board Glomar Challenger for this study. These

${ }^{1}$ van Hinte, J. E., Wise, S, W., Jr., et al., Init. Repts. DSDP, 93: Washington (U.S. Govt, Printing Office).

2 Address: Oceanography Program, The University of Michigan, Ann Arbor, MI 48109. were augmented with postcruise sampling from frozen core sections. Five sample groups contain closely bedded organic-carbon-rich and organic-carbon-lean strata. Hatteras Formation samples consist of one Turonian sample, six Cenomanian samples, and eight Albian samples. Three samples of Barremian age, five Hauterivian, and one Valanginian sample are from the Blake-Bahama Formation. All samples were frozen immediately after collection and remained frozen until analysis began.

The samples were freeze-dried for determination of their total carbon contents with a Hewlett-Packard 185B CHN Analyzer. Residual carbon was measured after $\mathrm{HCl}$ dissolution of carbonates and was considered to represent the total organic-carbon content. Percent calcium carbonate was calculated from the difference between initial and residual carbon contents. Organic-matter atomic $\mathrm{C} / \mathrm{N}$ ratios were determined from residual carbon values. Organic-carbon contents of the samples were calculated on a dry-weight basis $(\%)$ for the original, carbonate-containing sediment.

Stable carbon isotope ratios of the organic-carbon content of these samples were determined on carbonate-free samples using a VG Micromass 602 mass spectrometer calibrated with NBS-20 (carbonate) and NBS-22 (petroleum) standards. Data are corrected for ${ }^{17} \mathrm{O}$ and are presented relative to the PDB standard.

A two-stage extraction procedure was used to obtain the geolipid contents. Soxhlet extraction with toluene-methanol yielded the easily extractable, or free, lipids. A second extraction with $0.5 \mathrm{~N} \mathrm{KOH}$ in methanol-toluene provided the hydrolyzable, or bound, geolipids. Both fractions were treated with methanolic boron trifluoride to convert fatty acids to their methyl esters. Geolipid subfractions were separated by column chromatography on alumina over silica gel. The subfractions obtained contained alkanes and alkenes, aromatic hydrocarbons, fatty acid methyl esters, and hydroxy lipids including sterols and alkanols. Hydroxy compounds were silylated with bistrimethylsilyltrifluoroacetamide (BSTFA) prior to gas chromatography.

Splitless injection gas-liquid chromatography was employed to determine the types and amounts of components present in the geolipid subfractions. A Hewlett-Packard 5830 FID gas chromatograph equipped with a 20-m SE54 fused silica capillary column was used with hydrogen as the carrier gas. Quantification was achieved through the use of known amounts of internal standards added to each sample before column chromatography. Individual compounds are tentatively identified by retention times in this preliminary survey. Reported values have been corrected for mass discrimination over the wide molecular-weight range reported.

\section{LITHOLOGIC SETTING}

Cretaceous strata in the North Atlantic have been divided into the Plantagenet Formation, the Hatteras Formation, and the Blake-Bahama Formation on the basis 
of earlier DSDP sampling (cf. Jansa et al., 1978; Sheridan et al., 1983; Summerhayes and Masran, 1983). The rocks comprising these formations at Site 603 are detailed in the Site 603 chapter (this volume) and are only briefly described here. Black shales were found in rocks ranging in age from Santonian to Berriasian at Hole $603 \mathrm{~B}$ on the outer Hatteras Rise in the North American Basin (Fig. 1). Neither the lithologic settings nor the organic-carbon contents of these deposits are uniform over this considerable time span, although the common presence of turbidites and of bioturbation show some important similarities existed in the depositional environments. Santonian to late Turonian rocks consist of variegated claystones with sparse black shales and correspond to the Plantagenet Formation. The early Turonian to Aptian section contains abundant black shales interspersed among red and green claystones and corresponds to the Hatteras Formation. Limestones and sandstones with black claystone turbidites make up the Aptian-Berriasian BlakeBahama Formation. Cenomanian black shales contain the highest concentrations of organic carbon (Herbin et al., this volume; Meyers, this volume), and all black shales generally exist as thin strata surrounded by organic-carbon-poor rocks.

\section{RESULTS}

\section{Organic Carbon, C/N Values, and Carbon Isotopes}

\section{Hatteras Formation}

The seven black shales of the Hatteras Formation have a significantly higher concentration of organic carbon than the adjacent lighter-colored strata. Organic carbon averages $2.71 \%$ in the black shales and $0.28 \%$ in the adjacent strata (Table 1). McIver (1975) compiled an average value of $0.3 \%$ organic carbon for ancient deep-ocean sediments from DSDP Legs 1 through 33. This value may be considered the background level for normal deepocean sediments. The high concentrations found in the black shales, therefore, indicate unusual circumstances for their deposition.

$\mathrm{C} / \mathrm{N}$ ratios of Hatteras Formation black shales have averages significantly higher than adjacent green and red claystones. Based upon a survey of marine sediments,

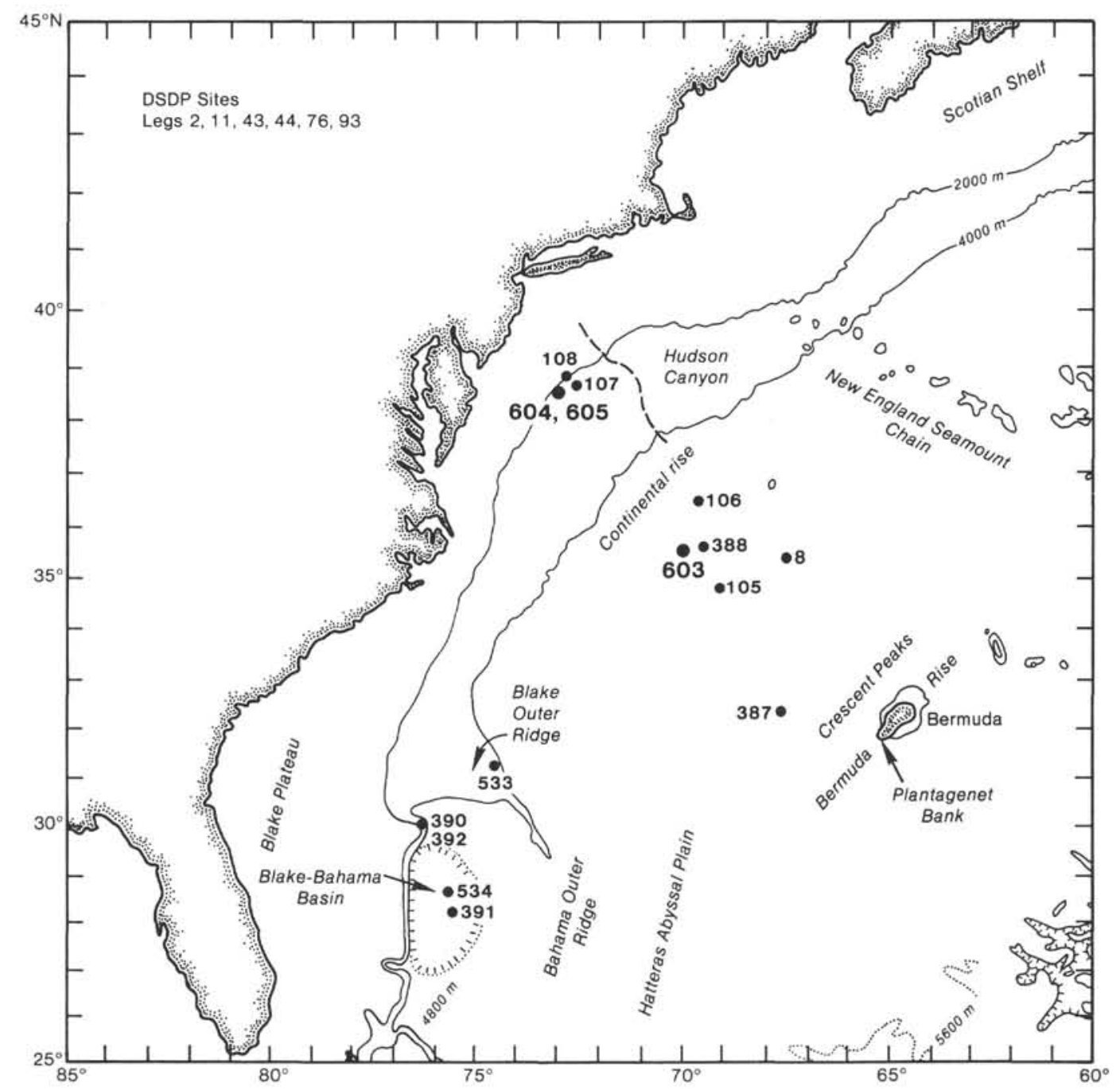

Figure 1. Location of DSDP Site 603 in relation to other DSDP sites in the western North Atlantic Ocean. 
Table 1. General descriptions of Cretaceous samples selected for organic geochemical comparison, Hole 603B, Hatteras and Blake-Bahama formations.

\begin{tabular}{|c|c|c|c|c|c|c|c|}
\hline $\begin{array}{l}\text { Core-Section } \\
\text { (interval in } \mathrm{cm} \text { ) }\end{array}$ & $\begin{array}{l}\text { Sub-bottom } \\
\text { depth (m) }\end{array}$ & Age & Lithology & $\begin{array}{c}\mathrm{CaCO}_{3} \\
(\%)\end{array}$ & $\begin{array}{l}\mathrm{C}_{\text {org }} \\
(\%)\end{array}$ & $\mathrm{C} / \mathrm{N}$ & $\delta^{13} \mathrm{C}_{\text {org }}$ \\
\hline \multicolumn{8}{|l|}{ Hatteras Formation } \\
\hline $33, \mathrm{CC}, 1-8$ & 1127.4 & Turonian & Black shale & 12 & 3.87 & 64.0 & -24.5 \\
\hline $34-2,85-87$ & 1129.9 & Cenomanian & Black shale & 5 & 7.02 & 52.9 & -23.8 \\
\hline $35-2,142-145$ & 1139.4 & Cenomanian & Green claystone & $<1$ & 0.25 & 14.6 & -24.2 \\
\hline $35-3,72-74$ & 1140.2 & Cenomanian & Black shale & 26 & 1.20 & 15.6 & -26.6 \\
\hline $37-4,119-123$ & 1160.2 & Cenomanian & Green claystone & 4 & 0.33 & 6.7 & -27.9 \\
\hline $37-4,123-126$ & 1160.2 & Cenomanian & Black shale & $<1$ & 2.18 & 19.7 & -26.4 \\
\hline $37-4,126-128$ & 1160.3 & Cenomanian & Green claystone & $<1$ & 0.47 & $<1$ & -24.3 \\
\hline $38-4,55-60$ & 1168.6 & Albian & Red-green claystone & $<1$ & 0.25 & $<1$ & -22.0 \\
\hline $38-4,83-86$ & 1168.8 & Albian & Green claystone & $<1$ & 0.19 & 1.6 & -24.6 \\
\hline $38-4,88-91$ & 1168.9 & Albian & Black shale & $<1$ & 0.98 & 28.7 & -27.1 \\
\hline $40-2,26-29$ & 1183.3 & Albian & Red claystone & $<1$ & 0.19 & $<1$ & -24.1 \\
\hline $40-2,37-41$ & 1183.4 & Albian & Green claystone & 2 & 0.30 & 35.1 & -23.2 \\
\hline $40-2,42-43$ & 1183.4 & Albian & Black shale & $<1$ & 0.82 & 24.0 & -27.7 \\
\hline $40-2,45-48$ & 1183.5 & Albian & Green claystone & $<1$ & 0.20 & 1.5 & -26.7 \\
\hline $40-2,51-54$ & 1183.5 & Albian & Red claystone & $<1$ & 0.31 & $<1$ & -24.8 \\
\hline $42-3,42-45$ & 1200.6 & Albian & Black shale & 4 & 2.89 & 87.5 & -24.9 \\
\hline \multicolumn{8}{|c|}{ Blake-Bahama Formation } \\
\hline $49-2,98-101$ & 1264.9 & Barremian & Black shale & 7 & 3.14 & 65.5 & -25.6 \\
\hline $53-4,140-144$ & 1306.7 & Barremian & Limestone & 43 & 0.53 & 55.0 & -27.4 \\
\hline $57-1,88-90$ & 1340.1 & Barremian & Black shale & 13 & 1.67 & 56.2 & -24.1 \\
\hline $66-2,68-70$ & 1425.9 & Hauterivian & Black shale & 17 & 1.96 & 6.3 & -24.8 \\
\hline $66-2,123-126$ & 1426.4 & Hauterivian & Limestone & 96 & 0.04 & 98.3 & -28.7 \\
\hline $66-2,133-135$ & 1426.5 & Hauterivian & Black shale & 19 & 0.99 & 35.7 & -25.6 \\
\hline $67-2,81-84$ & 1439.5 & Hauterivian & Black shale & 16 & 1.86 & 23.4 & -25.1 \\
\hline $71-5,135-139$ & 1476.1 & Hauterivian & Sandstone & 10 & 1.46 & $>100.0$ & -28.7 \\
\hline $76-3,135-139$ & 1515.9 & Valanginian & Limestone & 50 & 1.99 & 93.1 & -23.6 \\
\hline
\end{tabular}

Premuzic et al. (1982) suggest that $\mathrm{C} / \mathrm{N}$ ratios less than 8 indicate mostly marine organic matter, and values greater than 15 show a predominance of land-derived material. With increasing time of burial, however, $\mathrm{C} / \mathrm{N}$ ratios change as a result of diagenesis. Waples and Sloan (1980) report a gradual decrease in $\mathrm{C} / \mathrm{N}$ values from about 10 in Quaternary sediments to about 4 in Miocene samples, followed by increases in older sediments. Furthermore, $\mathrm{C} / \mathrm{N}$ values tend to be high in sediments where marine organic matter is well preserved, such as in Cenomanian black shales from the Angola Basin (Meyers et al., 1984).

Carbon isotope data provide further information about the sources of organic matter in these samples. In general, land-derived organic matter is more depleted in ${ }^{13} \mathrm{C}$ than is marine organic matter, although carbon isotope ratios appear to be sensitive to diagenetic modification in black shale deposits and hence should not, by themselves, be considered absolute determinants of source (Dean, Claypool, et al., 1984; Meyers et al., 1984). Hatteras Formation black shales average $-25.9 \% 0$ and range from -23.8 to $-27.7 \%$. Adjacent green and red claystones have a wide range of $\delta^{13} \mathrm{C}$ values, from -22.0 to $-29.9 \%$.

\section{Blake-Bahama Formation}

Organic-carbon percentages of the five Blake-Bahama Formation black shales average $1.92 \%$ (Table 1). Limestones and sandstones adjacent to the black shales average slightly lower values, with the exception of limestone Sample 603B-66-2, 123-126 cm, which has a value of $0.04 \%$ organic carbon.
$\mathrm{C} / \mathrm{N}$ ratios in the Blake-Bahama Formation are relatively high, averaging 59.3. There are two large deviations from this average. Sample 603B-71-5, 135-139 cm has an undetectable amount of nitrogen; therefore, the $\mathrm{C} / \mathrm{N}$ ratio is reported as greater than 100 . Sample 603B$66-2,68-70 \mathrm{~cm}$ has a $\mathrm{C} / \mathrm{N}$ value of 6.3 (Table 1 ).

Blake-Bahama black shales have $\delta^{13} \mathrm{C}$ values averaging $-25.0 \%$. Adjacent lithologies once again show a wide range of values from -23.6 to $-28.7 \%$ (Table 1 ).

\section{Extractable Alkanes, Fatty Acids, and Alkanols}

\section{Hatteras Formation}

Concentrations of extractable (free) and bound geolipids are given in Tables 2 and 3 in terms of parts per million of dry sample weight and also relative to the organic-carbon concentrations. In comparison to samples from DSDP Site 530 in the Angola Basin, the organic-carbon-lean samples contain about the same amounts of $n$ alkanes, but are richer in alkanoic acids and alkanols (Meyers et al., 1984). The black shale samples, in contrast, contain substantially lower concentrations than the black shales from the Angola Basin (Meyers et al., 1984) and often less than adjacent strata. It is evident that these black shales of the Hatteras Formation are geolipid-lean.

The free and bound geolipid distribution of the black shales and adjacent strata are compared in Figures 2 through 9. Long-chain-length geolipids, such as $\mathrm{C}_{27}-\mathrm{C}_{33}$ odd-numbered $n$-alkanes and $\mathrm{C}_{24}-\mathrm{C}_{32}$ even numbered $n$ alkanoic acids and $n$-alkanols, are present in all samples 
Table 2. Concentrations of solvent-extractable (free) and nonsolventextractable (bound) geolipid fractions obtained from Hole 603B samples from the Hatteras and Blake-Bahama formations.

\begin{tabular}{|c|c|c|c|c|c|c|c|}
\hline \multirow{2}{*}{$\begin{array}{l}\text { Core-Section } \\
\text { (interval in cm) }\end{array}$} & \multirow[b]{2}{*}{ Lithology } & \multicolumn{2}{|c|}{ n-Alkanes } & \multicolumn{2}{|c|}{$\begin{array}{l}\text { n-Alkanoic } \\
\text { acids }\end{array}$} & \multicolumn{2}{|c|}{ n-Alkanols } \\
\hline & & Free & Bound & Free & Bound & Free & Bound \\
\hline \multicolumn{8}{|l|}{ Hatteras Formation } \\
\hline $33, \mathrm{CC}, 1-8$ & Black shale & 2.9 & - & 24.0 & 7.8 & 11.9 & 3.2 \\
\hline $34-2,85-87$ & Black shale & 2.9 & - & 18.6 & 4.8 & 24.2 & 3.2 \\
\hline $37-4,119-123$ & Green claystone & 1.6 & 0.7 & 10.4 & 1.8 & 36.2 & 2.1 \\
\hline $37-4,123-126$ & Black shale & 3.3 & 0.4 & 10.1 & 5.5 & 11.2 & 2.2 \\
\hline $37-4,126-128$ & Green claystone & 0.8 & 0.5 & 15.3 & 3.2 & 18.5 & 2.9 \\
\hline $38-4,55-60$ & Red-green claystone & 1.7 . & 1.2 & 5.1 & 2.8 & - & - \\
\hline $38-4,83-86$ & Green claystone & 2.5 & 0.7 & 9.9 & 1.7 & - & - \\
\hline $38-4,88-91$ & Black shale & 2.2 & 3.4 & 8.8 & 3.1 & - & - \\
\hline $40-2,26-29$ & Red claystone & 1.9 & 10.4 & 6.5 & 1.1 & 15.1 & 1.3 \\
\hline $40-2,37-41$ & Green claystone & 1.5 & 0.2 & 9.2 & 0.4 & 13.8 & 0.7 \\
\hline $40-2,42-43$ & Black shale & 1.9 & 7.9 & 1.1 & 1,3 & 2.7 & 1.6 \\
\hline $40-2,45-48$ & Green claystone & 0.5 & 0.2 & 4.4 & 0.4 & 10.1 & 0.6 \\
\hline $40-2,51-54$ & Red claystone & 0.8 & 13.2 & 8.9 & 7.0 & 11.9 & 11.9 \\
\hline $42-3,42-45$ & Black shale & 7.7 & - & 38.8 & 3.6 & 65.6 & 3.3 \\
\hline \multicolumn{8}{|c|}{ Blake-Bahama Formation } \\
\hline $49-2,98-101$ & Black shale & 5.0 & 0.2 & 22.7 & 4.1 & 28.7 & 6.7 \\
\hline $53-4,140-144$ & Limestone & 1.7 & 0.1 & 10.6 & 1.7 & 14.0 & 1.4 \\
\hline $57-1,88-90$ & Black shale & 4.1 & -1.0 & 17.1 & 2.0 & 17.8 & 0.7 \\
\hline $66-2,68-70$ & Black shale & 3.8 & 0.2 & 18.0 & 4.7 & 17.1 & 1.4 \\
\hline $66-2,123-126$ & Limestone & 2.8 & 0.5 & 9.0 & 1.1 & 28.4 & 1.2 \\
\hline $66-2,133-135$ & Black shale & 4.0 & 0.4 & 32.9 & 6.2 & 25.5 & 1.6 \\
\hline $67-5,81-84$ & Black shale & 2.6 & 0.8 & 22.5 & 2.2 & 24.0 & 0.6 \\
\hline $71-5,135-139$ & Sandstone & 2.9 & 0.5 & 19.8 & 2.8 & 24.3 & 1.2 \\
\hline $76-3,135-139$ & Limestone & 2.4 & 0.5 & 19.1 & 1.2 & 15.4 & 1.4 \\
\hline
\end{tabular}

Note: All concentrations given in micrograms of geolipid components, as measured by gas chromatography, per gram dry weight of sample. Dash indicates that the concentration was not measured. and are characteristic of land plant waxes (Simoneit, 1978). Short-chain-length $n$-alkanes, such as $C_{17}-C_{21}$, are found more often in the bound fraction. These shortchain-length $n$-alkanes can be indicative of algal input (Simoneit, 1978). Comparison of the seven black shale samples reveals one dominant geolipid feature. A large proportion of terrigenous components is present in both the free and bound fractions. The importance of landderived geoliopids is especially conspicuous in the $n$-alkane distributions, which in this regard resemble distributions reported for black shales sampled from the Hatteras and Blake-Bahama formations at DSDP Sites 391 and 534, farther south of Site 603 in the North American Basin (Deroo et al., 1978; Erdman and Schorno, 1978; Stuermer and Simoneit, 1978; Herbin et al., 1983). The ratio of the isoprenoid hydrocarbons, pristane and phytane, is generally less than one in all of the Hatteras Formation samples.

Both the free and bound fatty acid distributions are dominated by $n-C_{16}$, which is a ubiquitous component characteristic of all biota (Figs. 2 through 9). Distribution of $n$-fatty acids between black shales and adjacent strata are very similar. The black shales show a strong land-derived geolipid signature. These distributions are similar to a black shale at Site 391, also from the Hatteras Formation (Cardoso et al., 1978).

Alkanol distributions in the Hatteras Formation show little variation between black shales and adjacent green and red claystones. Common to both the free and bound fractions in all of the samples is the dominance of the

Table 3. Geolipid concentrations from Hatteras and Blake-Bahama formation Hole 603B samples relative to organic carbon concentrations.

\begin{tabular}{|c|c|c|c|c|c|c|c|}
\hline \multirow{2}{*}{$\begin{array}{c}\text { Core-Section } \\
\text { (interval in cm) }\end{array}$} & \multirow[b]{2}{*}{ Lithology } & \multicolumn{2}{|c|}{$n$-Alkanes } & \multicolumn{2}{|c|}{$\begin{array}{l}\text { n-Alkanoic } \\
\text { acids }\end{array}$} & \multicolumn{2}{|c|}{$n$-Alkanols } \\
\hline & & Free & Bound & Free & Bound & Free & Bound \\
\hline \multicolumn{8}{|l|}{ Hatteras Formation } \\
\hline $33, \mathrm{CC}, 1-8$ & Black shale & 0.7 & - & 6.2 & 2.0 & 3.1 & 0.8 \\
\hline $34-2,85-87$ & Black shale & 0.4 & - & 2.6 & 0.7 & 3.4 & 0.5 \\
\hline $37-4,119-123$ & Green claystone & 4.8 & 2.1 & 31.5 & 5.5 & 109.7 & 6.4 \\
\hline $37-4,123-126$ & Black shale & 1.5 & 0.2 & 4.6 & 2.5 & 5.1 & 1.0 \\
\hline $37-4,126-128$ & Green claystone & 1.7 & 1.1 & 32.6 & 6.8 & 39.4 & 6.2 \\
\hline $38-4,55-60$ & Red-green claystone & 6.8 & 4.8 & 20.4 & 11.2 & - & - \\
\hline $38-4,83-86$ & Green claystone & 13.2 & 3.7 & 52.1 & 8.9 & - & - \\
\hline $38-4,88-91$ & Black shale & 2.2 & 3.5 & 9.0 & 3.2 & - & - \\
\hline $40-2,26-29$ & Red claystone & 10.0 & 54.7 & 34.2 & 5.8 & 79.5 & 6.8 \\
\hline $40-2,37-41$ & Green claystone & 5.0 & 0.7 & 30.7 & 1.3 & 46.0 & 2.3 \\
\hline $40-2,42-43$ & Black shale & 2.3 & 9.6 & 1.3 & 1.6 & 3.3 & 2.0 \\
\hline $40-2,45-48$ & Green claystone & 2.5 & 1.0 & 22.0 & 2.0 & 50.5 & 3.0 \\
\hline $40-2,51-54$ & Red claystone & 2.6 & 42.6 & 28.7 & 22.6 & 38.4 & 38.4 \\
\hline $42-3,42-45$ & Black shale & 2.7 & - & 13.4 & 1.2 & 22.7 & 1.1 \\
\hline \multicolumn{8}{|c|}{ Blake-Bahama Formation } \\
\hline $49-2,98-101$ & Black shale & 1.6 & 0.1 & 7.2 & 1.3 & 9.1 & 2.1 \\
\hline $53-4,140-144$ & Limestone & 3.2 & 0.2 & 20.0 & 3.2 & 26.4 & 2.6 \\
\hline $57-1,88-90$ & Black shale & 2.5 & 0.6 & 10.2 & 1.2 & 10.7 & 0.4 \\
\hline $66-2,68-70$ & Black shale & 1.9 & 0.1 & 9.2 & 2.4 & 8.7 & 0.7 \\
\hline $66-2,123-126$ & Limestone & 70.0 & 12.5 & 225.0 & 27.5 & 710.0 & 30.0 \\
\hline $66-2,133-135$ & Black shale & 4.0 & 0.4 & 33.2 & 6.3 & 25.8 & 1.6 \\
\hline $67-5,81-84$ & Black shale & 1.4 & 0.4 & 12.1 & 1.2 & 12.9 & 0.3 \\
\hline $71-5,135-139$ & Sandstone & 2.0 & 0.3 & 13.6 & 1.9 & 16.6 & 0.8 \\
\hline $76-3,135-139$ & Limestone & 1.2 & 0.3 & 9.6 & 0.6 & 7.7 & 0.7 \\
\hline
\end{tabular}

Note: Solvent-extractable (free) and nonsolvent-extractable (bound) concentrations in parts per million are divided by percent organic carbon for each geolipid fraction. Dash indicates that the concentration was not measured. 

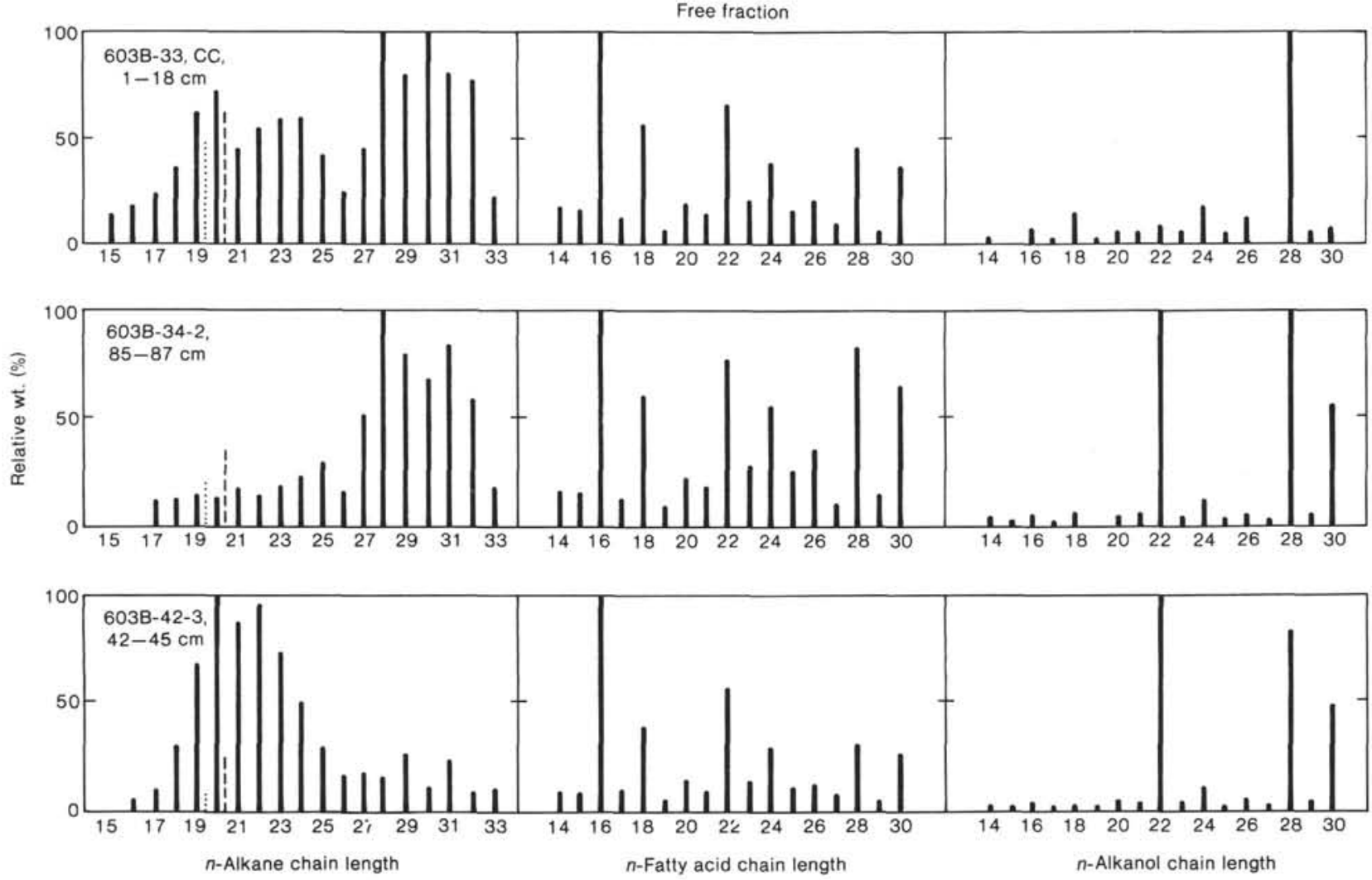

Figure 2. Distributions of free (solvent-extractable) geolipids from three Hatteras Formation black shales. Relative abundances are normalized to the major component in each sample. Isoprenoid hydrocarbons pristane and phytane are presented as dotted and dashed lines, respectively.
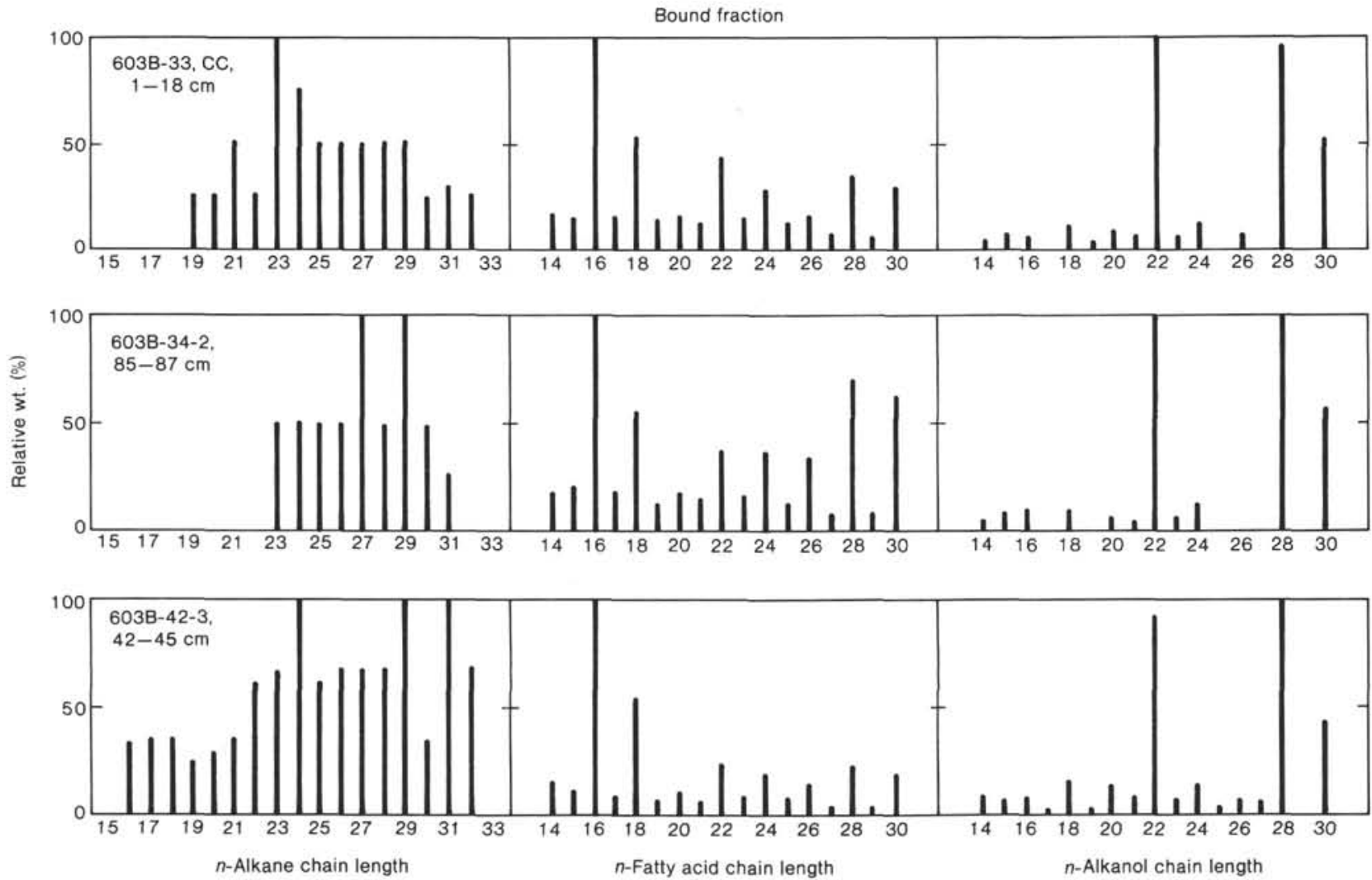

Figure 3. Distributions of bound (nonsolvent-extractable) geolipids from three Hatteras Formation black shales. See Figure 2 legend for details. 
Section 603B-37-4, free fraction
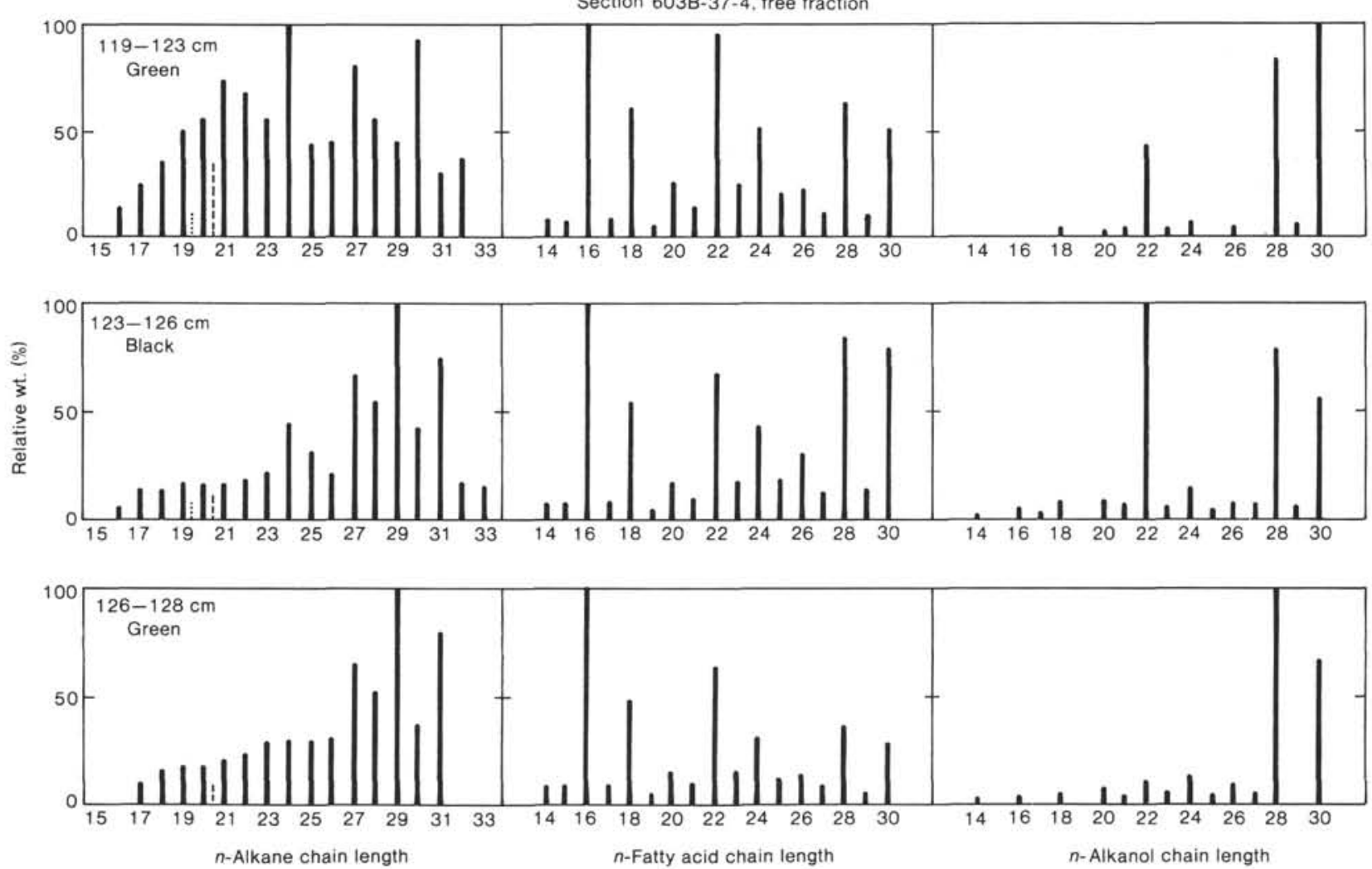

Figure 4. Distributions of free (solvent-extractable) geolipids from three closely spaced Cenomanian samples from the Hatteras Formation. See Figure 2 legend for details.
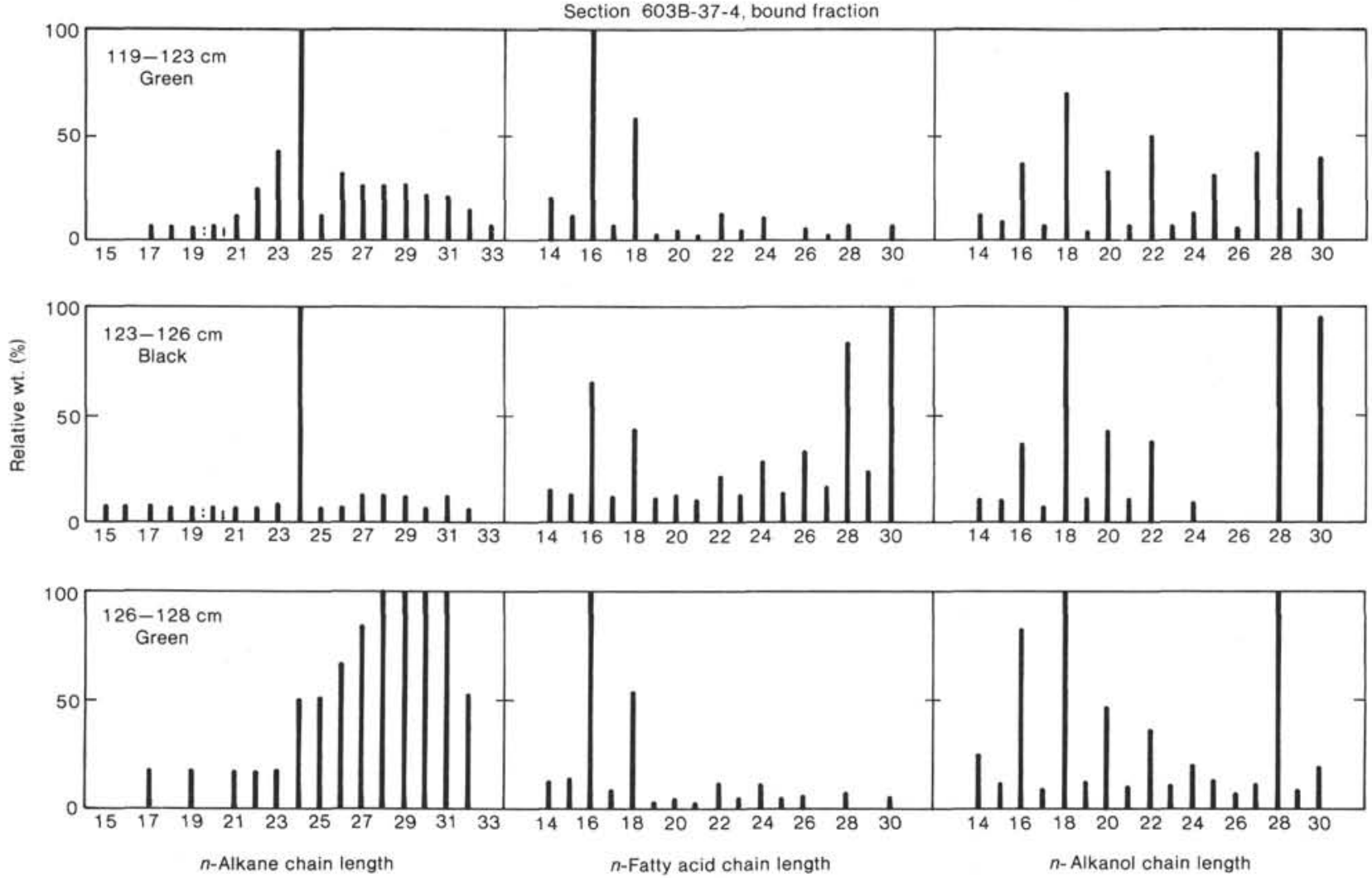

Figure 5. Distributions of bound (non-solvent-extractable) geolipids from three closely spaced Cenomanian samples from the Hatteras Formation. See Figure 2 legend for details. 
Section 603B-38-4, free fraction
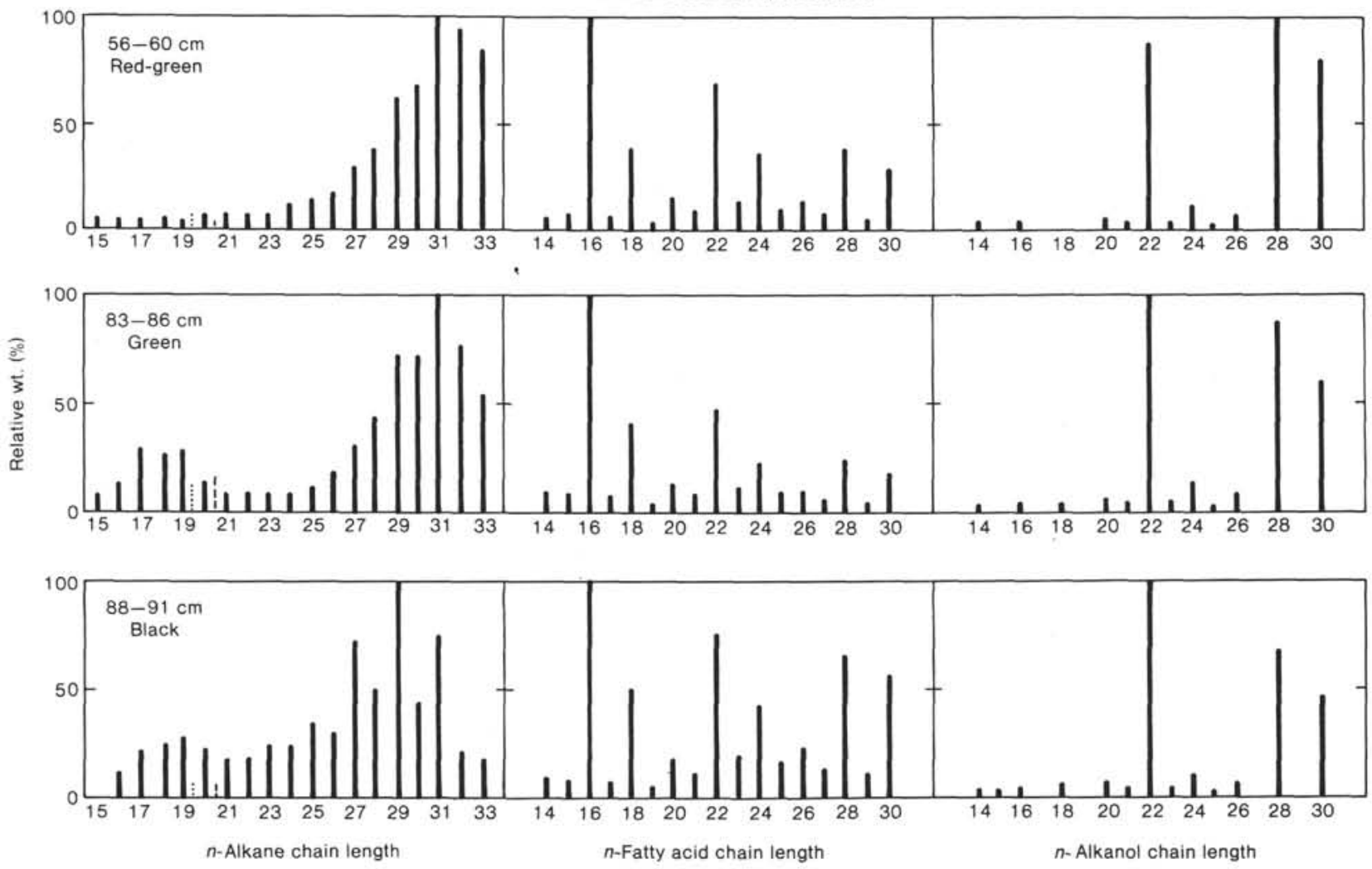

Figure 6. Distributions of free (solvent-extractable) geolipids from three closely spaced Albian samples from the Hatteras Formation. See Figure 2 legend for details.
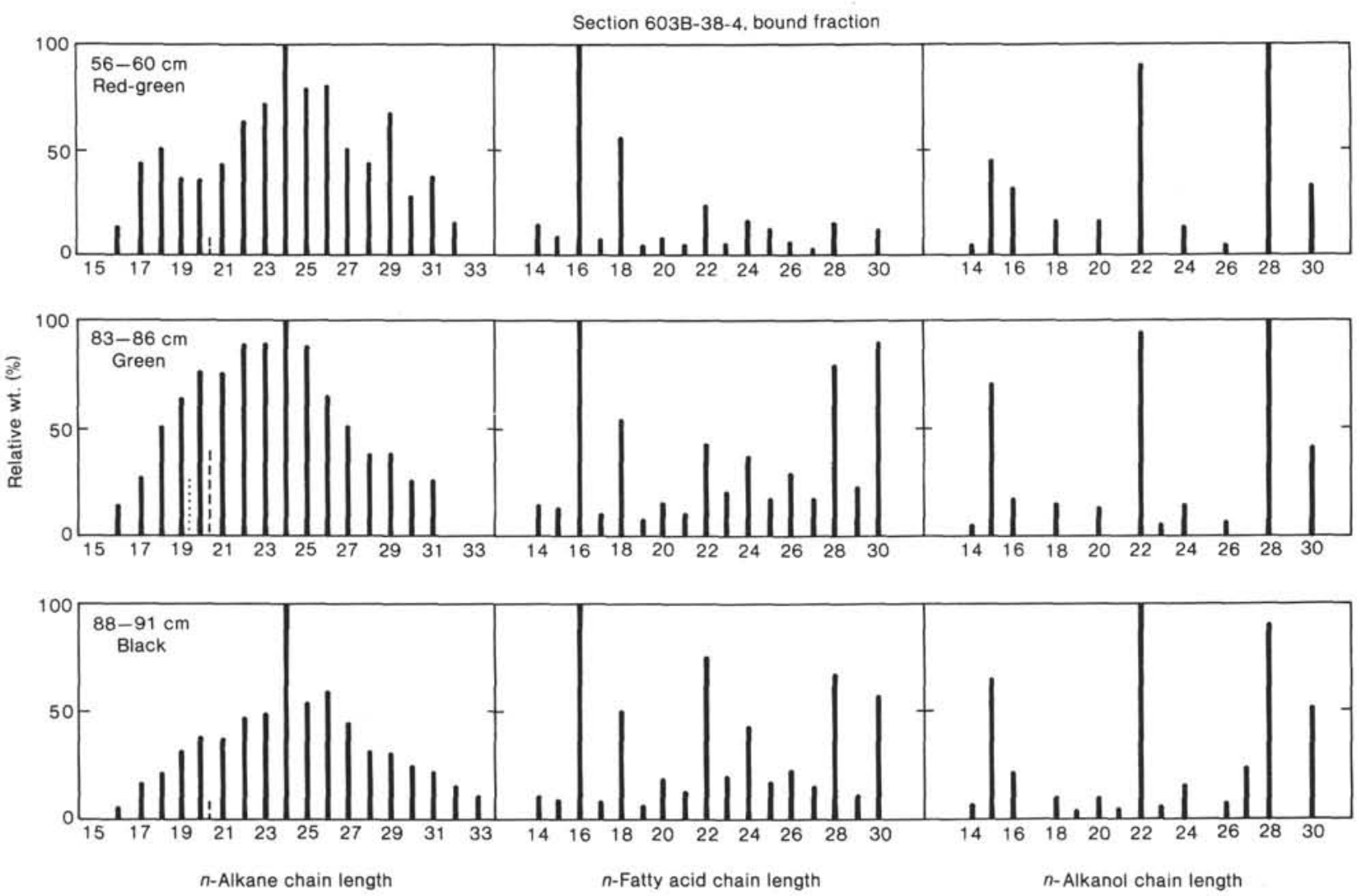

Figure 7. Distributions of bound (non-solvent-extractable) geolipids from three closely spaced Albian samples from the Hatteras Formation. See Figure 2 legend for details. 

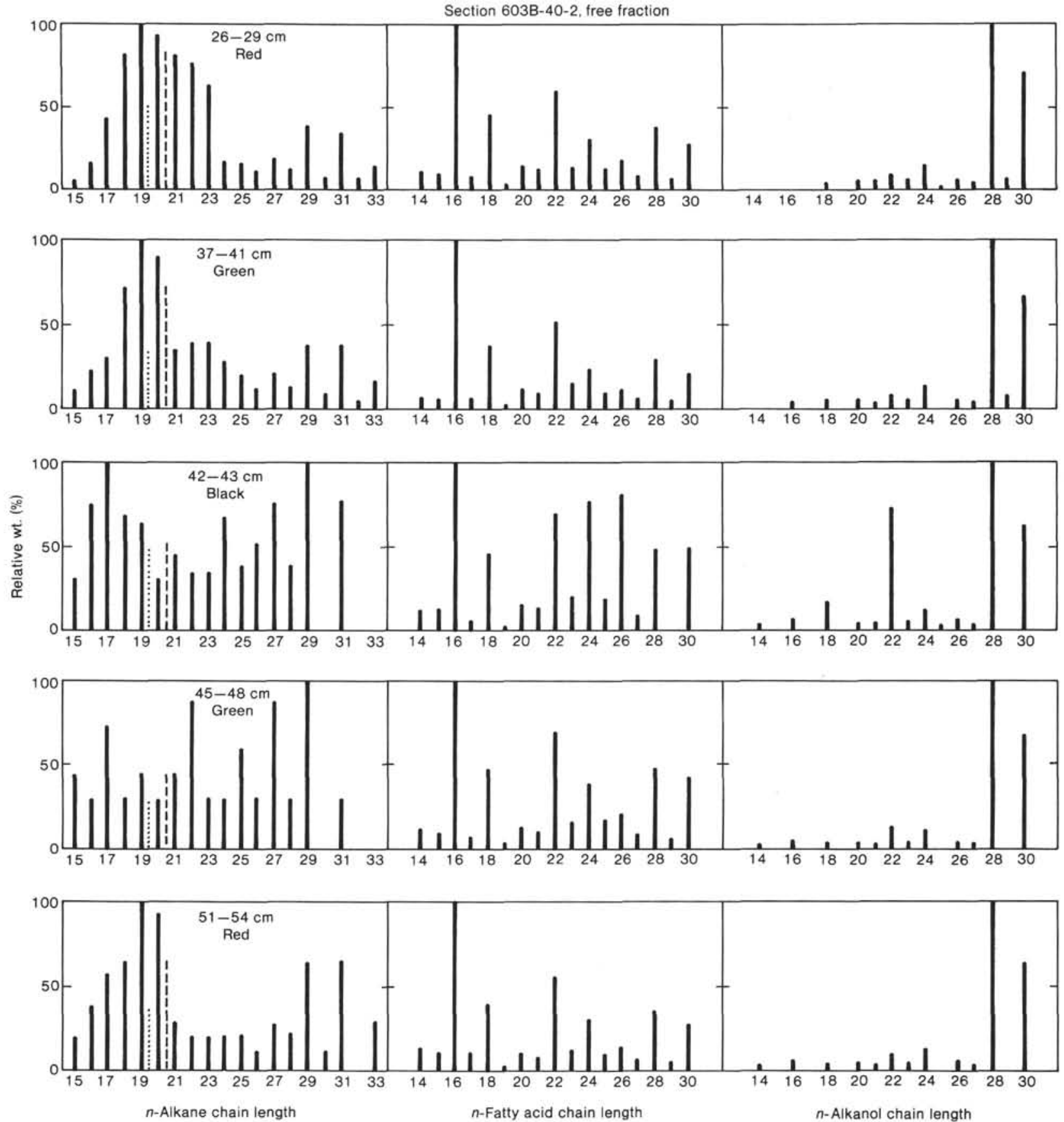

Figure 8. Distributions of free (solvent-extractable) geolipids from five closely spaced Albian samples from the Hatteras Formation. See

Figure 2 legend for details.

$\mathrm{C}_{28}$ and $\mathrm{C}_{30} n$-alkanols. Long-chain $n$-alkanols such as these have been interpreted to be indicators of terrigenous geolipids in marine sediments (Brassell et al., 1982). The majority of the samples contain large quantities of $\mathrm{C}_{22} n$-alkanol, which has been observed in other deepocean organic-lean sediments (Keswani et al., 1984) and may result from microbial processing of sediment organic matter.

\section{Blake-Bahama Formation}

Concentrations of extractable and bound geolipids are given in Tables 2 and 3 in terms of parts per million of dry sample weight and relative to the organic-carbon concentrations. Both the organic-carbon-rich and organiccarbon-lean samples follow the same observations in the Hatteras Formation. In comparison to the adjacent strata and other deep-ocean black-shales, these Blake-Bahama Formation shales are geolipid-lean.

Free and bound geolipid information for the BlakeBahama Formation samples are compared in Figures 10 through 15. Differences between the distribution of $n$ alkanes in organic-carbon-rich and organic-carbon-lean samples are not straightforward. All of the samples, however, have a strong terrigenous geolipid signature with 

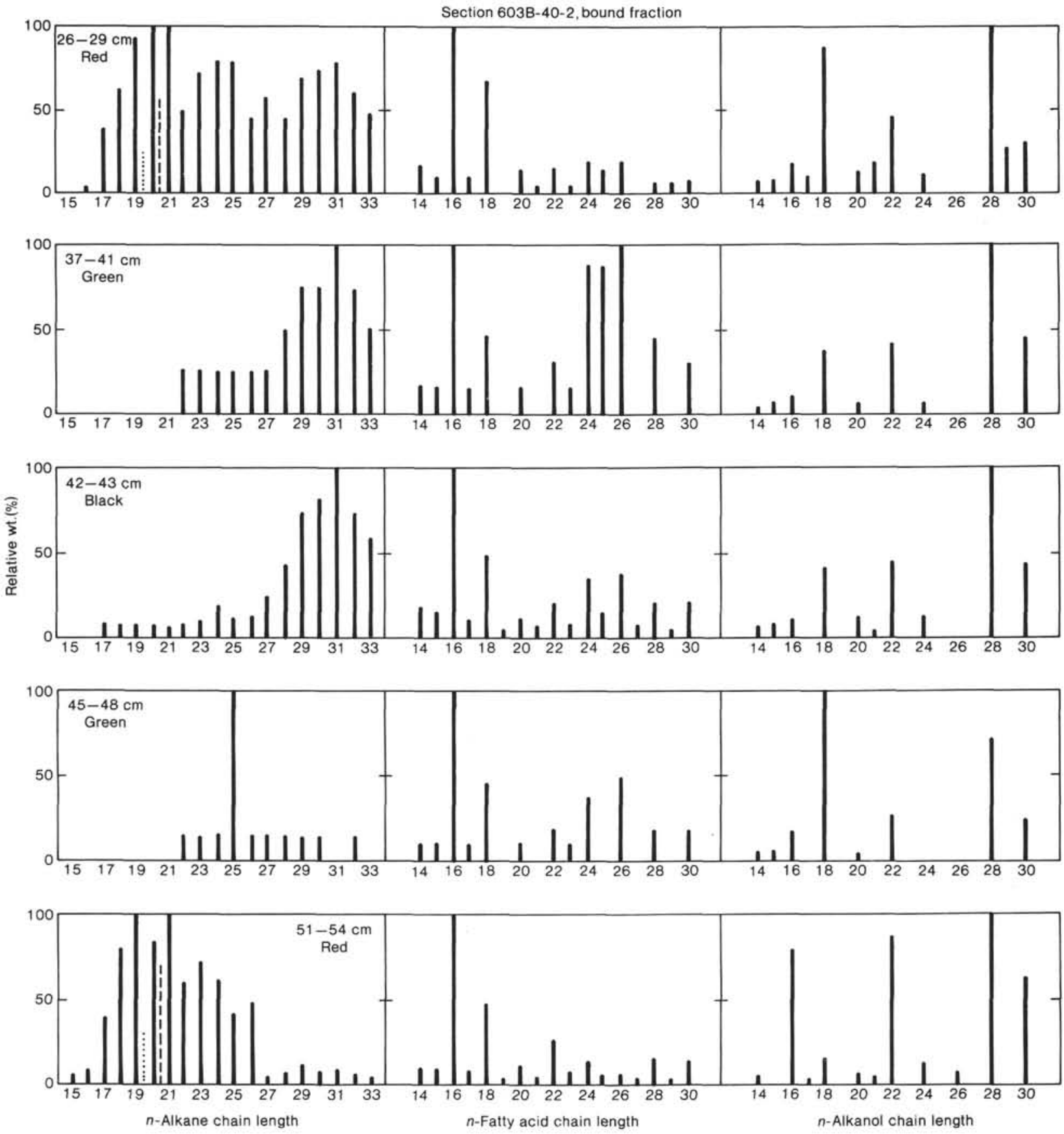

Figure 9. Distributions of bound (non-solvent-extractable) geolipids from five closely spaced Albian samples from the Hatteras Formation. See Figure 2 legend for details.

abundant $\mathrm{C}_{27}, \mathrm{C}_{29}, \mathrm{C}_{31}$, and $\mathrm{C}_{33} n$-alkanes. The ratio of the isoprenoid hydrocarbons, pristane and phytane, is generally less than one when available.

Unlike the $n$-alkanes, very little variability is observed in the $n$-fatty acid distributions between individual black shale units and adjacent strata. As in the Hatteras Formation, $\mathrm{C}_{16} n$-fatty acid dominates the distribution pattern. Significant amounts of longer chain lengths indicate strong land-derived $n$-fatty acids (Simoneit, 1978).

The distribution of both free and bound $n$-alkonols shows a terrigenous geolipid dominance. Short-chainlength algal inputs are not observed in the free fraction; however, some of the bound fractions from the BlakeBahama Formation contain $\mathrm{C}_{16}$ and $\mathrm{C}_{18} n$-alkanols. The presence of $\mathrm{C}_{22} n$-alkanol is variable. It ranges from low levels to the most abundant $n$-alkanol in Sample 603B36-3, 135-139 cm (Figs. 10 through 15).

\section{DISCUSSION}

\section{Hatteras Formation}

Organic matter in the black shales is a mixture of marine and varying proportions of continentally derived organic matter. The high $\mathrm{C} / \mathrm{N}$ values may record selective 
Free fraction
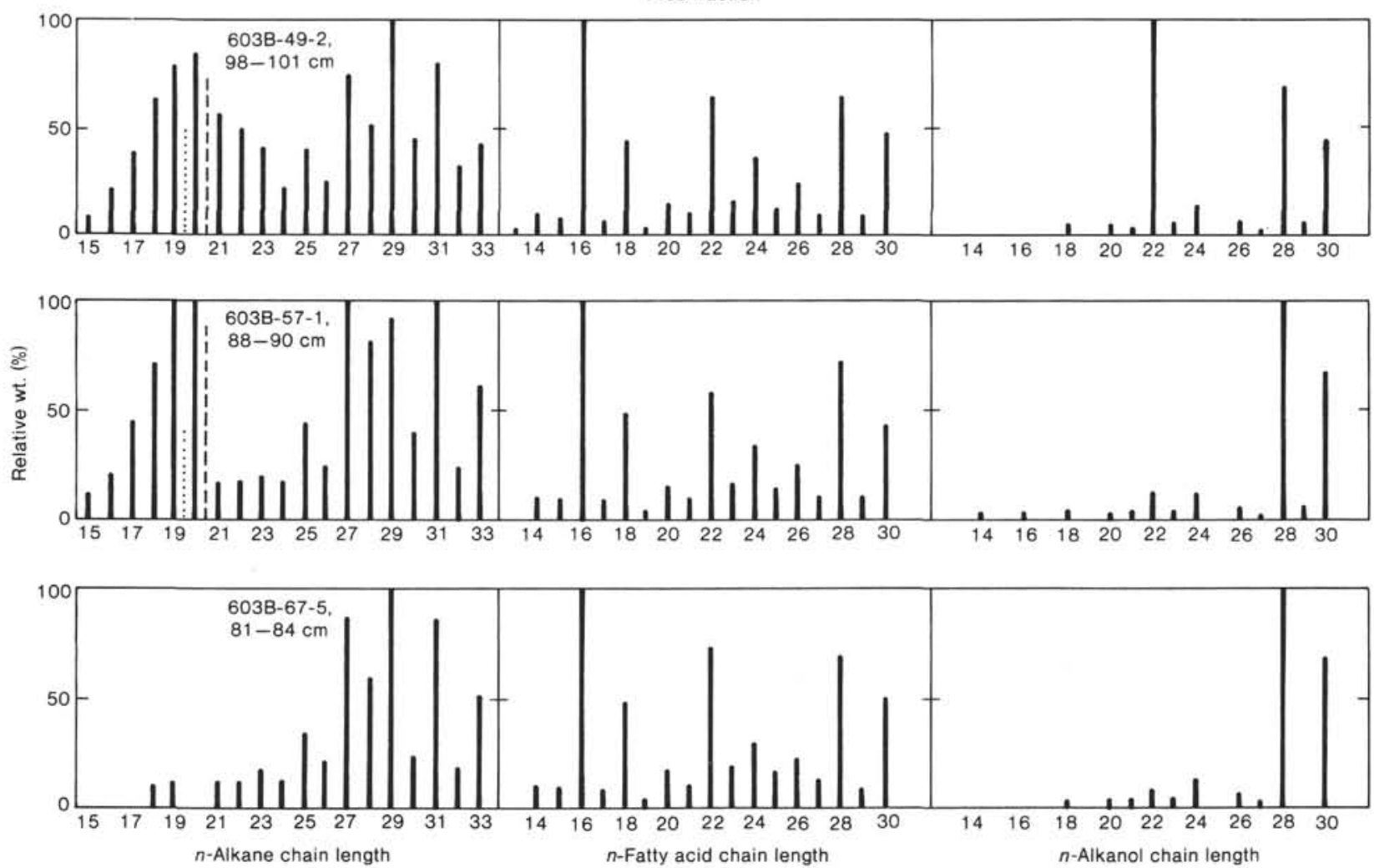

Figure 10. Distributions of free (solvent-extractable) geolipids from three Blake-Bahama Formation black shales. See Figure 2 legend for details.
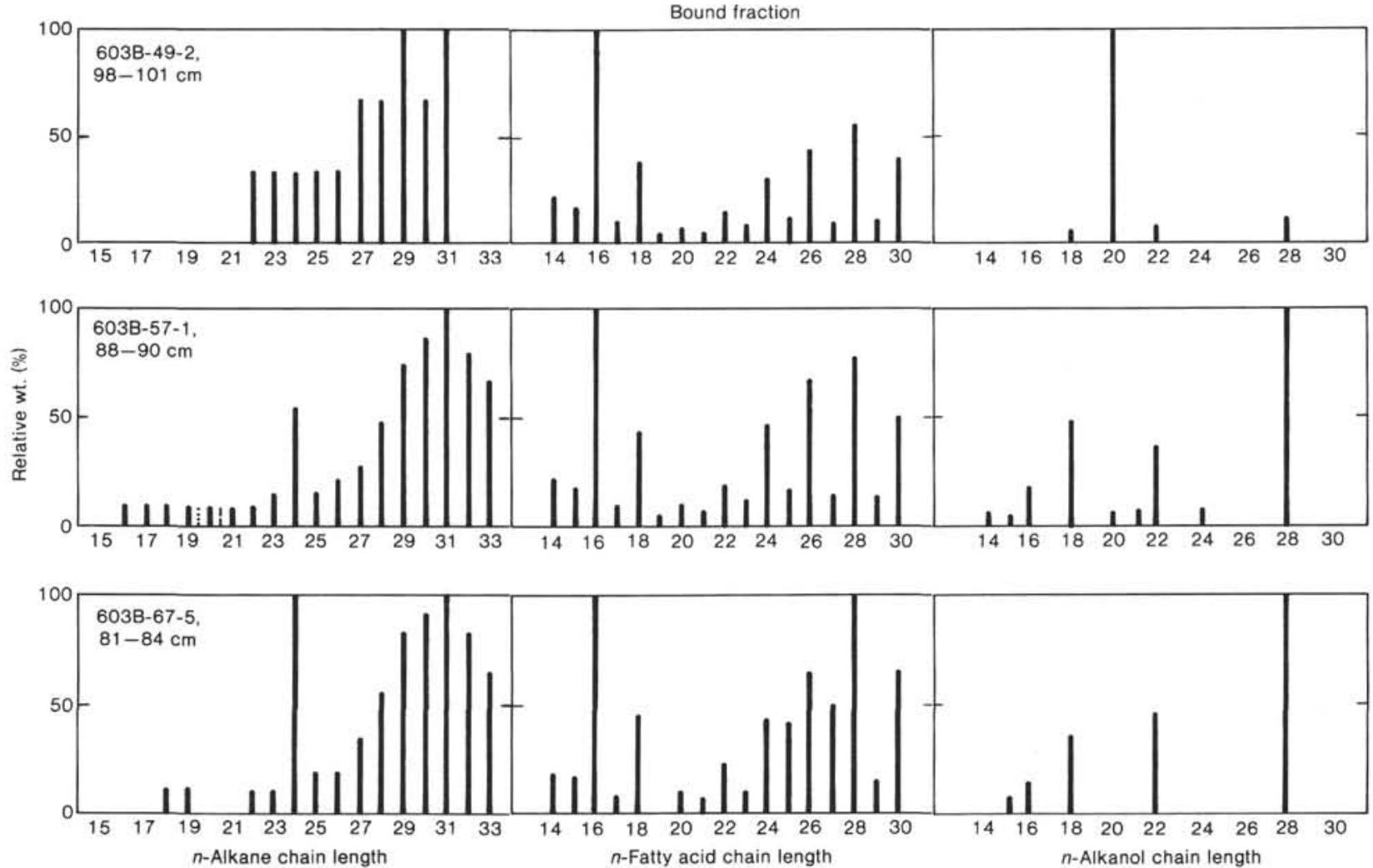

Figure 11. Distributions of bound (non-solvent-extractable) geolipids from three Blake-Bahama Formation black shales. See Figure 2 legend for details. 

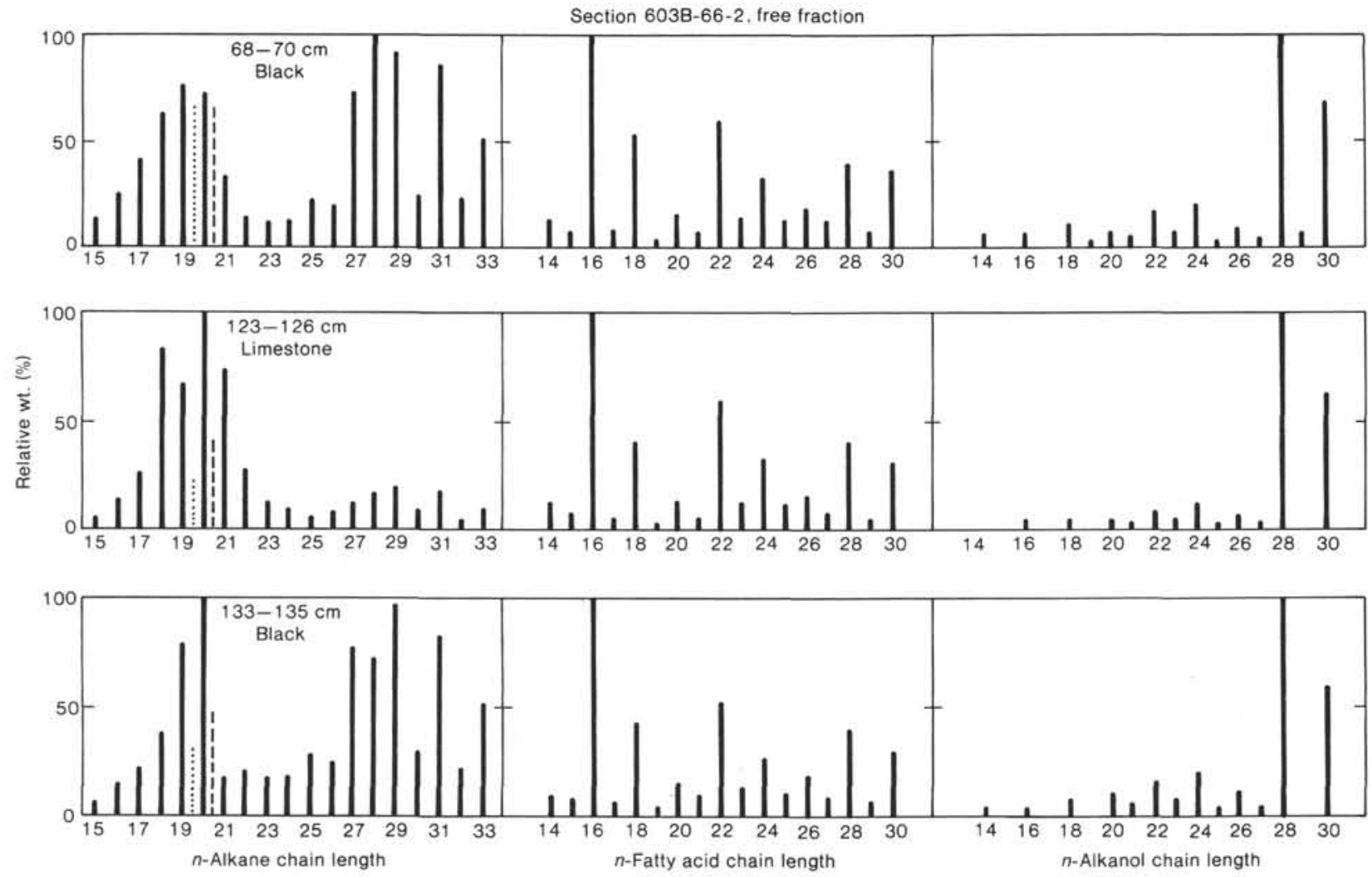

Figure 12. Distributions of free (solvent-extractable) geolipids from three closely spaced Hauterivian samples from the Blake-Bahama Formation. See Figure 2 legend for details.
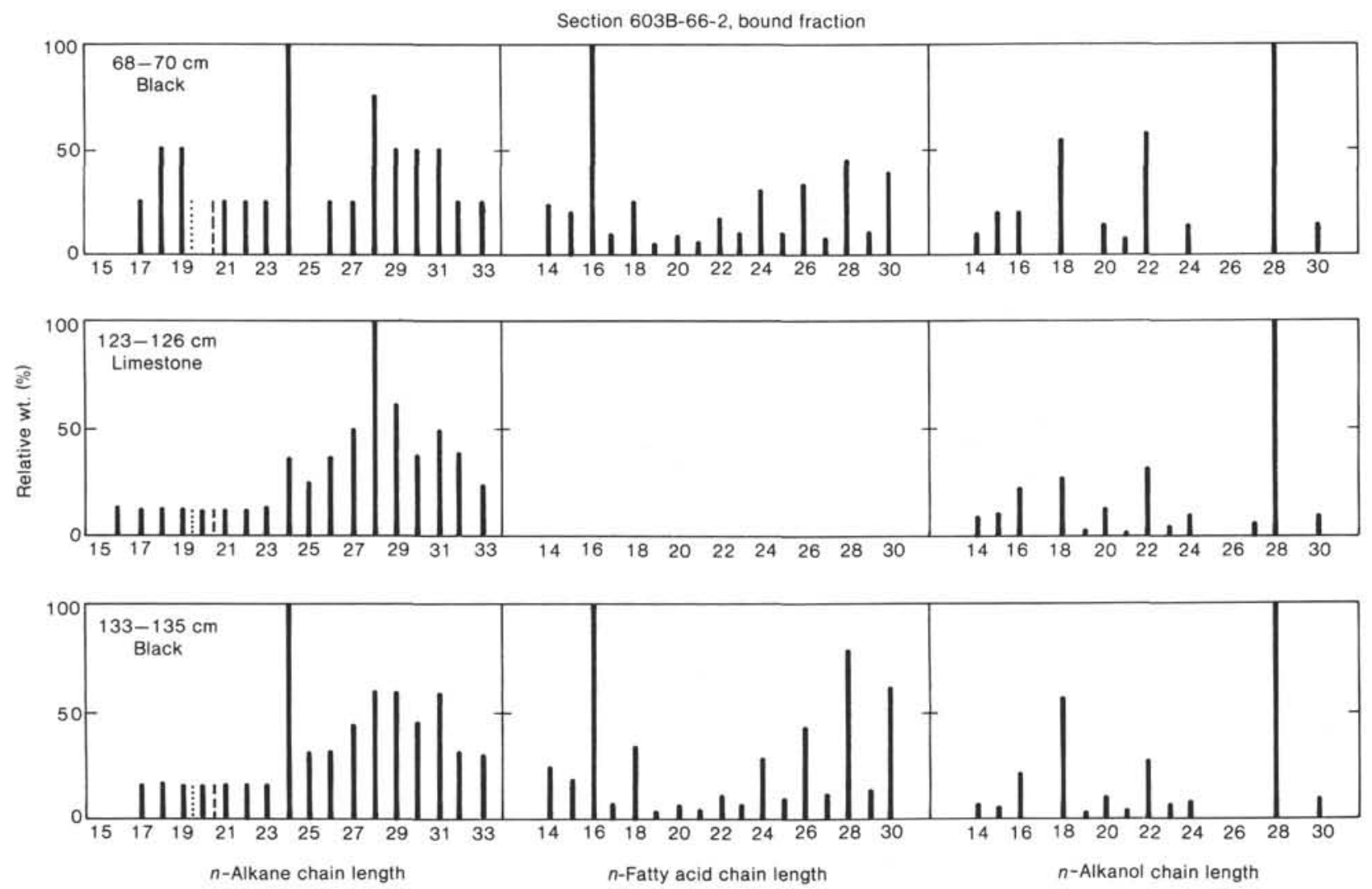

Figure 13. Distributions of bound (non-solvent-extractable) geolipids from three closely spaced Hauterivian samples from the Blake-Bahama Formation. See Figure 2 legend for details. 

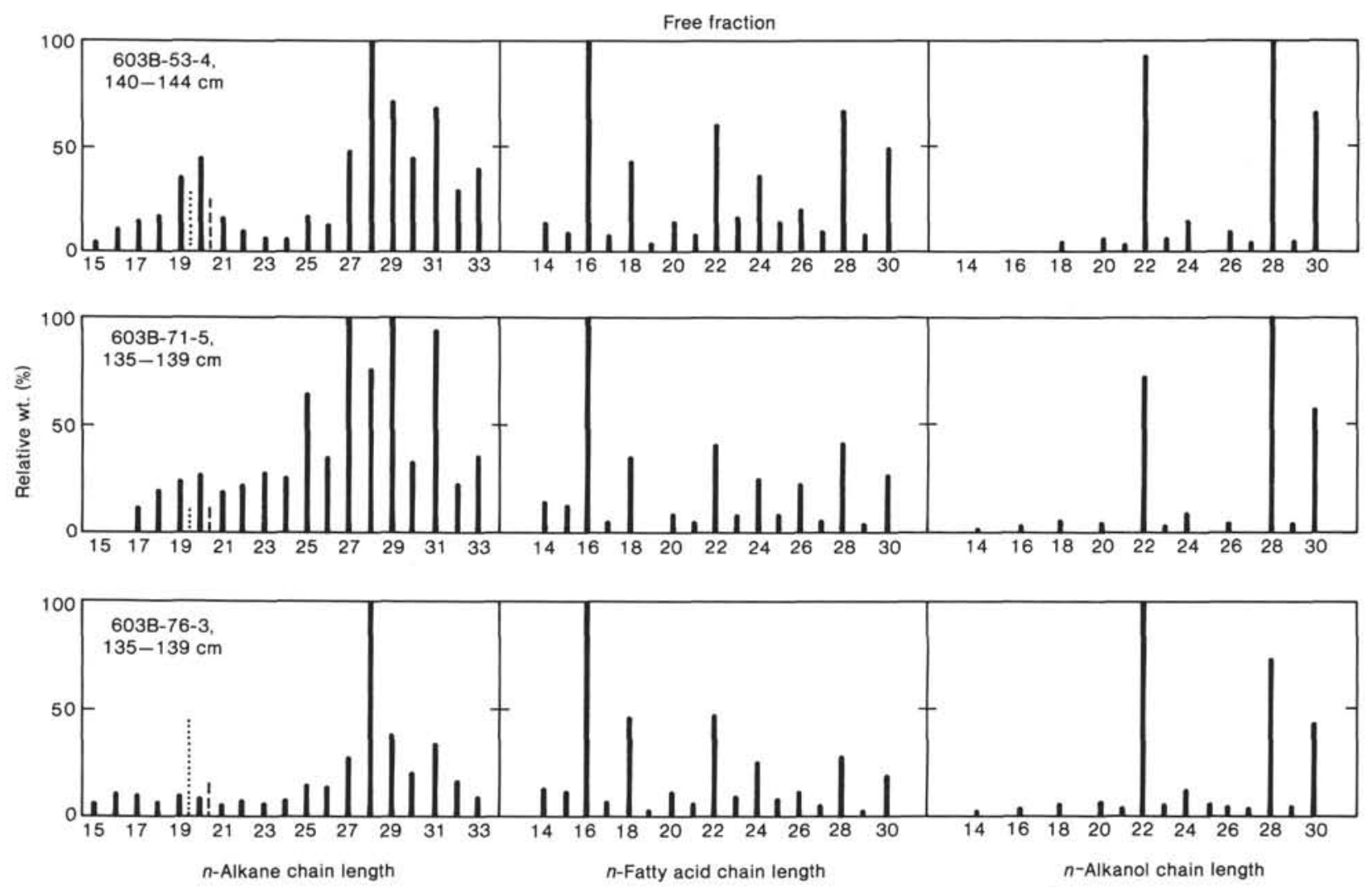

Figure 14. Distributions of free (solvent-extractable) geolipids from two limestones and one sandstone from the Blake-Bahama Formation. See Figure 2 legend for details.
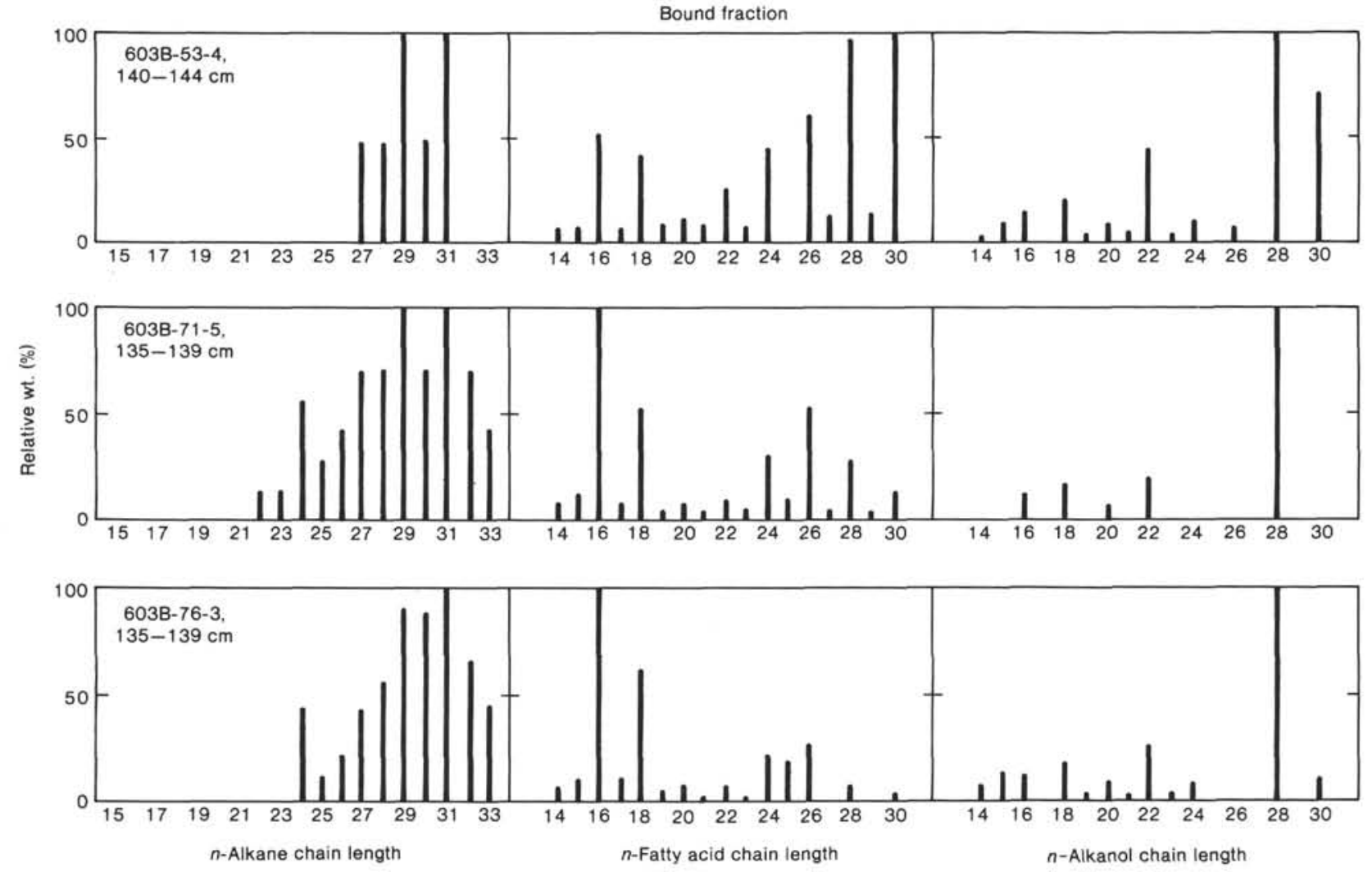

Figure 15. Distributions of bound (non-solvent-extractable) geolipids from two limestones and one sandstone from the Blake-Bahama Formation. See Figure 2 legend for details. 
preservation of carbonaceous components relative to marine organic nitrogenous components. Organic matter in the organic-carbon-lean green and red claystones of the Hatteras Formation appears to be made up of detrital, highly oxidized materials similar to those found in most deep-sea sediments (cf. Degens and Mopper, 1976). Such sediments commonly have low $\mathrm{C} / \mathrm{N}$ ratios in older strata.

Comparison of carbon isotope compositions of black shales with their adjacent strata shows a positive relationship between higher organic-carbon concentrations and a stronger marine isotope character in black shale samples (Fig. 16A). The isotope values of rocks surrounding the black shales display a wide range that suggests varying origins of the organic matter in these layers of turbiditic, organic-carbon-lean rock. This relationship implies that the organic-matter concentration of Hatteras Formation black shales is directly related to burial of greater proportions of marine organic matter superimposed upon a background of poorly preserved organic matter from variable sources. $\mathrm{C} / \mathrm{N}$ and $\delta^{13} \mathrm{C}$ values are both indicators of the source of organic matter. High $\mathrm{C} / \mathrm{N}$ values from vascular land plants should theoretically relate to light $\delta^{13} \mathrm{C}$ values and lower $\mathrm{C} / \mathrm{N}$ values from marine organic matter with heavier $\delta^{13} \mathrm{C}$ values. There is not such a relationship between $\mathrm{C} / \mathrm{N}$ values and $\delta^{13} \mathrm{C}$ values in these Hatteras Formation samples (Table 1). This further indicates the susceptibility of $\mathrm{C} / \mathrm{N}$ values, in particular, to diagenetic changes.

Geolipid distribution and concentrations in black shales and the adjacent strata are difficult to interpret. There appears to be no emergent geolipid pattern in relationship to other organic geochemical parameters. For example, three black shale samples-Samples 603B-33,CC, $1-18 \mathrm{~cm}$; 603B-34-2, $85-87 \mathrm{~cm}$; and 603B-42-3, 42-43 $\mathrm{cm}$-have dissimilar $n$-alkane geolipid distributions (Fig. 2). Sample 603B-34-2, $85-87 \mathrm{~cm}$ has an $n$-alkane geolipid pattern typical of terrigenous organic matter. The $\delta^{13} \mathrm{C}$ value for this sample, however, is the most marine in character compared to the other two black shales. Part of the explanation for this characteristic may arise from enhanced preservation of nonlipid components of sediment organic matter in black shales. Such dilution of geolipid concentrations is postulated for black shales relatively rich in organic carbon (Meyers et al., 1984). In black shales with relatively low amounts of organic carbon, such as Sample 603B-42-2, 42-40 cm, it appears that even the lipid components have been microbially reworked and nearly all of the remaining organic matter is detrital inert matter.

Fatty acid and alkanol concentrations in the black shales are high compared to other deep-ocean black shales (Meyers et al., 1984). The higher amounts of the latter two geolipid fractions may reflect larger proportions of waxy land-plant material in the Hatteras Formation samples, which is consistent with the geolipid distributions (Figs. 2 through 9). Turbidites are common throughout the Hatteras and Blake-Bahama formations; therefore, transport of continental organic matter to this deep-sea location is feasible. It is surprising, however, that the $n$-alkanol distributions are so similar despite considerable differences in total organic-carbon concentrations and in $n$-alkane distributions. Alkanols are considered to be more subject to microbial reworking than are alkanes, with the result that the $\mathrm{C}_{22} n$-alkanol suspected to indicate microbial activity is the major alkanol found in open-ocean sediments in which organic carbon concentrations are low (Keswani et al., 1984). It seems paradoxical that many of the Hatteras Formation black shales (Figs. 2 through 10) display major contributions

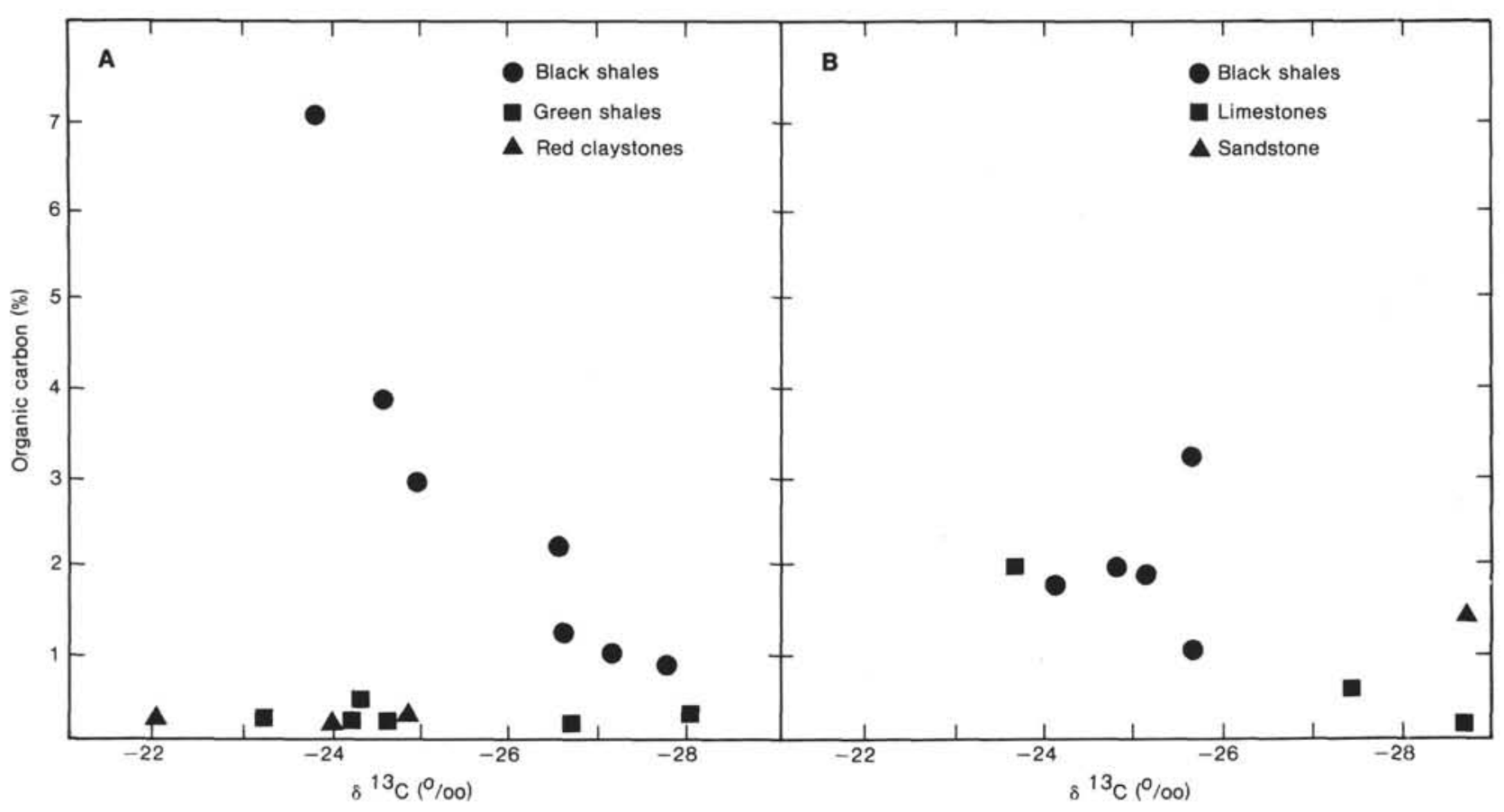

Figure 16. Organic carbon percentages vs. carbon isotope values, Hole 603B. A. Hatteras Formation samples. B. Blake-Bahama Formation samples. 
of the $\mathrm{C}_{22} n$-alkanol, unless these samples originally contained organic matter of the proper type and amount to support microbial activity.

Although pristane/phytane values below one have been proposed as an indication of anoxic depositional conditions (Didyk et al., 1978), methanogenic bacteria generate phytane during anaerobic fermentation of organic matter (Risatti et al., 1984). Because such fermentation can occur under anoxic conditions deeper in sediments as well as at an anoxic water/sediment boundary, low pristane/phytane ratios may record bacterial fermentation rather than a specific depositional condition.

\section{Blake-Bahama Formation}

Organic matter in the Blake-Bahama Formation black shales is predominantly terrigenous with small admixtures of marine organic matter. High $\mathrm{C} / \mathrm{N}$ values for the Blake-Bahama limestones and sandstone suggest these lithologies may contain substantial amounts of coaly material eroded from continental deposits. The Rock-Eval results (Meyers, this volume) show the relatively inert character of organic matter in samples of similar lithologies, even though some are fairly rich in organic carbon.

Comparison of carbon isotope compositions for the black shales, limestones, and sandstone does not show the clear relationship with organic-carbon content seen in the Hatteras Formation samples (Fig. 16B). Some relationship, however, may exist in the lighter-colored, usually organic-carbon-lean samples. The lean samples cluster around $-28.0 \%$. This cluster may indicate the normal background load of organic matter-highly terrigenous in nature. Sample $603 \mathrm{~B}-76-3,135-139 \mathrm{~cm}$ is the one exception; however, it does contain a larger amount of organic carbon.

All distributions of $n$-alkanes in the Blake-Bahama Formation black shales show a strong terrigenous character (Figs. 10 through 15). Shorter chain lengths, when present, do not show a major algal input. The absence of odd-chain-length predominance may indicate considerable bacterial reworking (Simoneit, 1978). Fatty acid and alkanol concentrations are high compared to other deep-ocean black-shales, most likely for the same reasons already outlined for the Hatteras Formation samples.

\section{General}

The proportion of continental and marine organic matter present in black shale samples from the western North Atlantic varies considerably. Although most of the organic matter appears to be terrigenous (Katz and Pheifer, 1982), the marine fraction increases with distance from North America (Tissot et al., 1980; Summerhayes and Masran, 1983). This pattern has been explained by Summerhayes and Masran (1983) to reflect the decrease in turbiditic dilution of marine sediments with continental materials as distance from shore increases. An exception to this generality occurs in Cenomanian black shales, where large proportions of marine organic matter are found at Site 105 (Summerhayes, 1981) located on the continental rise and in turbiditic environments. This ex- ception illustrates the regional and temporal variability that can exists in the mixture of organic-matter types in black shales. On the basis of carbon isotope ratio variability, the organic-carbon-lean rocks surrounding black shale samples from Site 603 also appear to demonstrate considerable variation in their proportions of marine and terrigenous organic matter.

The paleoceanographic picture that emerges is that during the Cretaceous, the western North Atlantic appears to have been a narrow sea filled with oxygenated water. It appears to have received an abundant supply of terrigenous clastics from North America and to have had at best moderate levels of marine productivity. How did black shales form under such conditions? Whereas it is possible that bottom-water anoxia existed from time to time in the basins comprising the proto-Atlantic, it is unlikely that enough marine organic matter would survive sinking through the predominantly oxygenated water column to form black shales. It is more likely that the organic material reached the deep-ocean sites of black shale deposition in the company of turbidity flows, and preservation occurred from rapid burial in the oxygenated deep basins.

This scenario of downslope transport and redeposition is essentially the same as earlier proposed by Dean, $\mathrm{Ar}$ thur, et al. (1984) for Site 530 in the Angola Basin and by Robertson and Bliefnick (1983) for Site 534 in the Blake-Bahama Basin, and it helps explain the variability in organic character present in the sediments of the western North Atlantic. This explanation is based upon the assumption that each occurrence of black shale deposition is a local or regional event, loosely linked to other such events by global paleoceanographic conditions. Changes in climate, sea level, or oceanic circulation might destabilize ocean margin sediments and initiate turbidity flows at numerous locations around the North Atlantic. Such flows need not be absolutely synchronous and need not contain the same organic-matter content. Except for those originating where the oxygen-minimum layer intercepts the bottom, most would actually be poor in organic carbon; all would have their proportions of marine and terrigenous materials controlled by local conditions. On the seafloor, these flows would form fanlike deposits that would overlap and interfinger, rarely creating the continuous layers like those formed under shallow epicontinental seas. Although each black shale deposit would be initiated by a common set of global or oceanwide conditions, its individual characteristics would be determined by regional or local factors.

\section{CONCLUSIONS}

1. The content and character of organic matter in Cretaceous black shales from DSDP Site 603 in the western North Atlantic are quite variable.

2. Consistent with their large fraction of terrigenous organic matter, the black shales from Site 603 are relatively poor in extractable alkanes, alkanoic acids, and alkanols.

3. The lack of correspondence in isotope values between the black shales and their adjacent strata, despite 
similarities in geolipid distributions, implies differences in sources of the bulk, nonlipid organic matter.

4. The black shales represent short episodes of enhanced burial of organic matter within a general setting of poor preservation of carbonaceous materials. A prevailing oxygenated depositional setting is indicated by faunal burrowing, oxidized minerals, and low concentrations of organic carbon in most of the Cretaceous rocks from the western North Atlantic.

5. A scenario of downslope transport by turbidity flows from ocean margin locations within oxygen minima and redeposition in deep-ocean settings is invoked to explain black shale formation at Site 603 and other western North Atlantic locations.

\section{ACKNOWLEDGMENTS}

We thank the Deep Sea Drilling Project for providing the samples used in this study and for giving P. A. Meyers the opportunity to participate in Leg 93 . We are especially grateful to K. C. Lohman and his staff for the use of the carbon isotope mass spectrometer and to J. Powaser for laboratory assistance. This work was partially supported by the U. S. National Science Foundation.

\section{REFERENCES}

Arthur, M. A., 1979. North Atlantic Cretaceous black shales: The record at Site 398 and a brief comparison with other occurrences. In Ryan, W. B. F., Sibuet, J.-C. et al., Init. Repts. DSDP, 47, Pt. 2 : Washington (U.S. Govt. Printing Office), 719-138.

Brassell, S. C., Eglinton, G., and Maxwell, J. R., 1982. Preliminary lipid analyses of two Quaternary sediments from the Middle America Trench, southern Mexico transect, Deep Sea Drilling Project Leg 66. In Watkins, J. S., Moore, J. C., et al., Init. Repts. DSDP, 66: Washington (U.S. Govt. Printing Office), 557-580.

Cardoso, J. N., Wardroper, A. M. K., Watts, C. D., Barnes, P. J., Maxwell, J. R., Eglinton, G., Mound, D. G., and Speers, G. C., 1978. Preliminary organic geochemical analyses; Site 391, Leg 44 of the Deep Sea Drilling Project. In Benson, W. E., Sheridan, R. E., et al., Init. Repts. DSDP, 44: Washington (U.S. Govt. Printing Office), 617-623.

Dean, W. E., Arthur, M. A., and Stow, D. A. V., 1984. Origin and geochemistry of Cretaceous deep-sea black shales and multicolored claystones, with emphasis on Deep Sea Drilling Project Site 530, southern Angola Basin. In Hay, W. W., Sibuet, J.-C., et al., Init. Repts. DSDP, 75: Washington (U.S. Govt Printing Office), 819-844.

Dean, W. E., Claypool, G. E. and Thiede, J., 1984. Accumulation of organic matter in Cretaceous oxygen-deficient depositional environments in the central Pacific Ocean. Org. Geochem., 7:39-51.

Degens, E. T., and Mopper, K., 1976. Factors controlling the distribution and early diagnensis of organic material in marine sediments. In Riley, J. P., Chester, R. (Eds.), Chemical Oceanography (Vol. 6): London (Academic Press), 59-113.

Deroo, G., Herbin, J. P., Roucaché, J. R., Tissot, B., Albrecht, P., and Dastillung, M., 1978. Organic geochemistry of some Cretaceous claystones from Site 391, Leg 44, western North Atlantic. In Benson, W. E., Sheridan, R. E., et al., Init. Repts. DSDP, 44: Washington (U.S. Govt. Printing Office), 593-603.

Didyk, B. M., Simoneit, B. R. T., Brassell, S. C., and Eglinton, G., 1978. Geochemical indicators of paleoenvironmental conditions of sedimentation. Nature, 272:216-222.

Erdman, J. G., and Schorno, K. S., 1978. Geochemistry of carbon: Deep Sea Drilling Project Leg 44. In Benson, W. E., Sheridan, R. E., et al., Init. Repts. DSDP, 44: Washington (U.S. Govt. Printing Office), 605-615.

Graciansky, P. C. de, Bourbon, M., Lemoine, M., and Sigal, J., 1981. The sedimentary record of mid-Cretaceous events in the western Tethys and central Atlantic Oceans and their continental margins. Eclogae Geol. Helv., 47:353-367.
Graciansky, P. C. de, Brosse, E., Deroo, G., Herbin, J.-P., Montadert, L., Müller, C., Sigal, J., and Schaff, A., 1982. Les formations d'âge Crétacé de l'Atlantique Nord et leur matière organique: paléogéographie et milieux de dépôt. Rev. Inst. Fr. Pet., 37: 275-337.

Herbin, J. P., Deroo, G., and Roucaché, J., 1983. Organic geochemistry in the Mesozoic and Cenozoic formations of Site 534, Leg 76, Blake-Bahama Basin, and comparison with Site 391, Leg 44. In Sheridan, R. E., Gradstein, F. M., et al., Init. Repts. DSDP, 76: Washington (U.S. Govt. Printing Office), 481-493.

Jansa, L., Gardner, J. V., and Dean, W. E., 1978. Mesozoic sequences of the central North Atlantic. In Lancelot, Y., Seibold, E., et al., Init. Repts. DSDP, 41: Washington (U.S. Govt. Printing Office), 991-1031.

Katz, B. J., and Pheifer, R. N., 1982. Characteristics of Cretaceous organic matter in the Atlantic. In Watkins, J., and Drake, C. (Eds.), Geology of Continental Margins. Am. Assoc. Pet. Geol. Mem., 34:617-628.

Keswani, S. R., Dunham, K. W, and Meyers, P. A., 1984. Organic geochemistry of late Cenozoic sediments from the subtropical South Atlantic. Mar. Geol., 61:25-42.

McIver, R., 1975. Hydrocarbon occurrences from JOIDES Deep Sea Drilling Project. Proc. Ninth World Petrol. Congr. 269-280.

Meyers, P. A., Leenheer, M. J., Kawka, O. E., and Trull, T. W., 1984. Enhanced preservation of marine-derived organic matter in Cenomanian black shales from the southern Angola Basin. Nature, 312: 356-359.

Premuzic, E. T., Benkovitz, C. M., Gaffney, J. S., and Walsh, J. J., 1982. The nature and distribution of organic matter in the surface sediments of world oceans and seas. Org. Geochem., 4:63-77.

Risatti, J. B., Rowland, S. J., Yon, D., and Maxwell, J. R., 1984. Stereochemical studies of acyclic isoprenoids-XII. Lipids of methanogenic bacteria and possible contributions to sediments. Org. Geochem., 6:93-104.

Robertson, A. H. F., and Bliefnick, D. M., 1983. Sedimentology and origin of Lower Cretaceous pelagic carbonates and redeposited clastics, Blake-Bahama Formation, Deep Sea Drilling Project Site 534, western equatorial Atlantic. In Sheridan, R. E., Gradstein, F. M., et al., Init. Repts. DSDP, 76: Washington (U.S. Govt. Printing Office), 795-828.

Sheridan, R. E., Gradstein, F. M., and Shipboard Scientific Party, 1983. Site 534: Blake-Bahama Basin. In Sheridan, R. E., Gradstein, F. M., et al., Init. Repts. DSDP, 76: Washington (U.S. Govt. Printing Office), 141-340.

Simoneit, B. R. T., 1978. The organic chemistry of marine sediments. In Riley, J. P., and Chester, R. (Eds.), Chemical Oceanography (Vol. 7): London (Academic Press), 233-311.

Stuermer, D. H., and Simoneit, B. R. T., 1978. Varying sources for the lipids and humic substances at Site 391, Blake-Bahama Basin, Deep Sea Drilling Project Leg 44. In Benson, W. E., Sheridan, R. E., et al., Init. Repts. DSDP, 44: Washington (U.S. Govt. Printing Office), 587-591.

Summerhayes, C. P., 1981. Organic facies of middle Cretaceous black shales in the deep North Atlantic. Am. Assoc. Pet. Geol. Bull., 65: 2364-2380.

Summerhayes, C. P., and Masran, T. C., 1983. Organic facies of Cretaceous and Jurassic sediments from Deep Sea Drilling Project Site 534 in the Blake-Bahama Basin, western North Atlantic. In Sheridan, R. E., Gradstein, F. M., et al., Init. Repts. DSDP, 76: Washington (U.S. Govt. Printing Office), 469-480.

Thierstein, H. R., 1979. Paleoceanographic implications of organic carbon and carbonate distribution in Mesozoic deep-sea sediments. In Talwani, M., Hay, W., and Ryan, W. B. F. (Eds.), Deep Drilling Results in the Atlantic Ocean: Continental Margins and Paleoenvironment: Washington (Am. Geophys. Un.), pp. 249-274.

Tissot, B. P., Demaison, G., Masson, P. Deteil, J. R., and Combaz, A., 1980. Paleoenvironment and petroleum potential of the midCretaceous black shales in the Atlantic basins. Am. Assoc. Pet. Geol. Bull., 64:2051-2063.

Tucholke, B. E., and Vogt, P. R., 1979. Western North Atlantic: Sedimentary evolution and aspects of tectonic history. In Tucholke, B. E., Vogt, P. R., et al., Init. Repts. DSDP, 43: Washington (U.S. Govt. Printing Office), 791-825. 
K. W. DUNHAM, P. A. MEYERS, P. L. DUNHAM

Waples, D. W, 1983. Reappraisal of anoxia and organic richness, with emphasis on Cretaceous of North Atlantic. Am. Assoc. Pet. Geol. Bull., 67:963-978.

Waples, D. W., and Sloan, J. R., 1980. Carbon and nitrogen diagenesis in deep sea sediments. Geochim. Cosmochim. Acta., 44:14631470.

Weissert, H., 1981. The environment of deposition of black shales in the Early Cretaceous: An ongoing controversy. In Warme, J. E., Douglas, R. G., and Winterer, E. L. (Eds.), The Deep Sea Drilling Project: A Decade of Progress. Soc. Econ. Paleontol. Mineral. Spec. Publ., 32:547-560.

Date of Initial Receipt: 5 April 1985

Date of Acceptance: 4 December 1985 